\title{
Lateral ramps as an aid to the unroofing of deep-crustal rocks: Seismic evidence from the Grenville province
}

\author{
Andrew Hynes \\ Department of Earth and Planetary Sciences, McGill University, Montreal, Quebec, Canada \\ David Eaton \\ Department of Earth Sciences, University of Western Ontario, London, Ontario, Canada
}

\begin{abstract}
We suggest that lateral ramps in the basement to orogenic wedges may be important agents in the rapid unroofing of deeply buried continental crust. Our suggestion is based on a study of the distribution of high-pressure metamorphosed continental rocks in the Mesoproterozoic Grenvillian orogen in eastern Quebec. These rocks were buried to depths of more than $50 \mathrm{~km}$ through crustal thickening during a continental collision and were then rapidly unroofed. They are currently exposed in a $100 \mathrm{~km} \mathrm{x}$ $60 \mathrm{~km}$ lobate embayment north of the Manicouagan Reservoir. Using a combination of surface structural data and seismic reflection data from Lithoprobe Line 55 , we reconstruct the three-dimensional form of the high-pressure rocks. Our reconstruct-ion methods are based on demonstrable correlations between the attitudes of gneissic layering at the surface and the attitudes of reflectors on the seismic profile. They make extensive use of the fact that much of the seismic reflectivity on Line 55 comes from outside the vertical plane of the seismic line, because of the sinuous nature of the line and its obliquity to tectonic strike. The validity of the reconstructions is demonstrated by the generation of a synthetic seismogram from the interpreted geometry that is very similar to the observed seismogram. Our reconstruction shows that a steep lateral ramp extends to the base of the crust immediately behind the broad lobe of highpressure rocks at the surface. The lateral ramp probably provided a favorable pathway for the extrusion of deep-seated rocks from the deep crust, and their transport onto the foreland.
\end{abstract}

\section{Introduction}

The weighted average thickness of continental crust is about $41 \mathrm{~km}$ [Christensen and Mooney, 1995]. At convergent plate margins, and particularly in continental-collision zones, it may be considerably thicker, although an upper limit of 70 to $80 \mathrm{~km}$ is probably provided by its tendency to spread gravitationally at that stage [England and Houseman, 1986, 1989]. The recognition of continental rocks that have experienced pressures of metamorphism equivalent to depths of more than $100 \mathrm{~km}$ in, for example, the Western Alps [Chopin, 1987], the Western Gneiss region of Norway

Copyright 1999 by the American Geophysical Union.

Paper number 1998TC900032.

0278-7407/99/1998TC900032\$12.00
[Andersen and Jamtveit, 1990; Andersen et al., 1991], and the Dabie Shan of China [Wang et al., 1992], is widely thought to indicate partial subduction of continental crust into the mantle [cf. Dewey et al., 1993]. There has been considerable discussion of mechanisms whereby rocks buried to such depths could be returned to the surface, and the suggestion that such return is driven by the intrinsic buoyancy of continental crust relative to the surrounding mantle [Hsü, 1991] has received support from physical modeling [Chemenda et al., 1995], although other factors, like delamination of the descending slab [Andersen et al., 1991], changes in the profile of the lower plate [Hynes et al., 1996], and resistance from the rigid lithospheric mantle of the upper plate [Hurich, 1996] may also be important. Once continental crust has returned to the same level as the Moho in the upper plate, however, or if it was not subducted into the mantle in the first place, but merely buried to great depth in a zone of crustal thickening, it has little positive buoyancy [cf. Hacker et al., 1995], and other factors must be sought for the rapid transport of the material to shallow crustal levels. Two general mech-anisms that may be responsible are extensional collapse [Platt, 1986] and the dynamic maintenance of orogenic wedges with continual addition of new material from below and behind, and its removal from above [e.g., Davy and Gillet, 1986; Jamieson and Beaumont, 1988]. In this paper we argue for the importance of a more specific feature that may aid the rapid unroofing of deep-crustal continental rocks and which may determine where they occur within orogens. This feature is the presence of lateral ramps at the bases of orogenic wedges. We develop the argument using a region of high-pressure metamorphosed continental rocks in the Mesoproterozoic Grenvillian orogen of eastern Quebec. By combining surface structural data and seismic reflection data, we construct a three-dimensional picture of subsurface geometry. We demonstrate that the distribution of high-pressure rocks is spatially closely related to a crustalscale lateral ramp and suggest that this lateral ramp provided a channel through which the rocks obtained easy and rapid access to shallow crustal levels.

\section{Geological Setting}

The Grenvillian orogen of eastern Ontario, Quebec, Labrador and northern New York State is a broad zone of rocks exhibiting high-grade metamorphism of Mesoproterozoic age and is generally interpreted as due to widespread crustal thickening following a continental collision [e.g., 
Rivers, 1997]. In Quebec and Labrador, rocks correlative to those in the foreland to the northeast can be traced far into the orogen [e.g., Rivers et al., 1989] and were in some cases buried to depths of more than $50 \mathrm{~km}$ during the orogeny [Rivers and Mengel, 1988; Indares, 1993, 1997]. The Grenvillian orogen encompasses several terranes that have experienced a variety of discrete Proterozoic orogenic events, including the Labradorian orogeny at $\sim 1650 \mathrm{Ma}$ [Gower et al., 1992] and the Elzevirian orogeny at $\sim 1200 \mathrm{Ma}$ [Easton, 1992], but the Grenvillian orogeny itself is considered to have occurred between 1190 and $850 \mathrm{Ma}$ [Rivers, 1997]. There is little evidence to indicate that the present limits of the Grenvillian orogenic belt encompass a suture related to the Grenvillian collision. The belt appears to consist of a crustalscale imbricate stack of tectonic slices that was assembled against the Archean nucleus of the Superior province to the northwest during earlier Proterozoic orogenies and then reworked as a result of northwest directed shortening of the southeastern margin of Laurentia during a Grenvillian collision for which the suture lay farther to the southeast [e.g., Davidson, 1995; Rivers, 1997]. Deep burial of the rocks of the Grenvillian foreland was therefore probably not due to partial subduction at a Wadati-Benioff zone. Instead, it reflects crustal thickening away from the collision zone.

\section{Geology of the Manicouagan Region}

This paper is concerned with the high-pressure metamorphosed rocks of the Manicouagan Imbricate Zone [Indares, 1997; A. Indares et al., Tectono-thermal evolution of deep crust in a Mesoproterozoic continental collision setting: The Manicouagan example, submitted to Canadian Journal of Earth Sciences, 1998, hereinafter referred to as submitted paper] (Figure 1) in the eastern Quebec part of the Grenvillian orogen. In the Manicouagan region, the northwestern limit of the Grenvillian orogenic belt, the Grenville Front, separates Archean Superior province crystalline rocks to the northwest from Archean rocks reworked in the Grenvillian to the southeast (Figure 1). The reworked Archean is tectonically overlain by Gagnon terrane, which consists largely of Paleo-proterozoic quartzofeldspathic and pelitic metasediments, marble, quartzite and iron formation of the Knob Lake Group, together with abundant mafic sills [Rivers, 1980], but also includes some reworked Archean, Superior-province base-ment. In the west of the region shown in Figure 1, rocks of Gagnon terrane are imbricated with Archean basement in a Grenvillian-age ductile thick- and thin-skinned thrust belt (A. Indares and T. Rivers, unpublished map, 1998) (Figure 1). In the northeast, the fold-thrust character of northern Gagnon terrane is progressively overprinted by map-scale upright northwest trending cross-folds [Clarke, 1977; Rivers, 1983] (Figure 1).

The Manicouagan Imbricate Zone consists of a stack of imbricated fault slices thrust onto Gagnon terrane and is exposed in a lobate arc to the north of the Manicouagan Reservoir [Indares, 1997] (Figure 1). It comprises at least four imbricated units. The lowest three, comprising Lelukuau terrane, consist of thrust slices of a dismembered anorthositemangerite-charnockite-granulite complex [Indares et al., 1998]. Layering dips generally easterly in the west and southerly in the east (A. Indares et al., submitted paper, 1998) (Figure 1). Northeast of the Manicouagan Reservoir, the upper unit, Tshenukutish terrane, consists predominantly of diorite with rafts of supracrustal rocks (metapelite, marble and quartzite) [Indares et al., 1998]. The central part of the Manicouagan Reservoir is largely obscured by Triassic volcanics related to a meteoritic impact but, to the southwest, Tshenukutish terrane reappears as the Southwest and Island domains, consisting of granitoid intrusives with sporadic metasedimentary screens. Layering in these domains dips consistently to the southeast (Figure 1).

Hart Jaune terrane and Berthé terrane tectonically overlie the Manicouagan Imbricate Zone east and southeast of the Manicouagan Reservoir, respectively. The contact between the Manicouagan Imbricate Zone and Hart Jaune terrane is the Hart Jaune shear zone (HJSZ, Figure 1), a ductile structure with late normal displacement that strikes toward the southwest into the reservoir. It cannot be traced across the reservoir because of younger cover, but it is inferred to reappear on the southern shore as the Triple Notch shear zone (TNSZ; Figure 1), which juxtaposes the Island domain (of Tshenukutish terrane) to Berthé terrane. Hart Jaune terrane and Berthe terrane are separated by the Gabriel shear zone (GaSZ, Figure 1), a thrust [Hynes and St-Jean, 1997] that swings from steeply SSW dipping near Highway 389 to southeast dipping on islands in the reservoir farther west.

Hart Jaune terrane consists predominantly of granulitefacies metagabbros and layered two-pyroxene metabasites, with subordinate calc-silicates and metapelites. Gneissic layering in Hart Jaune terrane dips uniformly steeply to the southeast (Figure 1). Berthé terrane is deformed into a largescale, reclined, south plunging fold, the Berthé nappe. The northern limb of the Berthe nappe dips southeast, and the southern limb dips southwest. The outer part of the nappe is occupied by the Canyon domain, consisting of massive granitoids enclosing large rafts of metapelite. The inner part, the Gabriel domain, consists of well-layered migmatitic quartzofeldspathic gneisses of probable metasedimentary origin, with concordant amphibolite sheets, a thick sheet of enderbite (orthopyroxene-bearing alkali feldspar granite) and other granitoid rocks, and a large body of recrystallized anorthosite, the Berthé anorthosite. The Canyon domain is separated from the Gabriel domain by the folded NW-vergent Highway shear zone (HWSZ; Figure 1).

Rocks of the Manicouagan Imbricate Zone are largely of Labradorian ( $1630 \mathrm{Ma}$ ) and Pinwarian (1467 Ma) age [Indares et al., 1998] and were probably already attached to North America at the time of the Grenvillian continental collision [Rivers, 1997]. They and adjacent slices of Gagnon terrane exhibit widespread evidence of metamorphism at great depths [Indares, 1997; A. Indares et al., submitted paper, 1998]. Microprobe studies have provided evidence for metamorphism at pressures as high as $1800 \mathrm{MPa}$ in the upper slices of Lelukuau terrane, and 1500 to $1700 \mathrm{MPa}$ in Tshenukutish terrane (A. Indares et al., submitted paper, 1998). This metamorphism occurred during the Grenvillian orogeny, at 1050 to $1020 \mathrm{Ma}$ [Indares et al., 1998] with progressively younger ages for the metamorphism toward the top of the pile, accompanied by evidence of metamorphic overprinting at lower pressures [A. Indares et al., submitted 


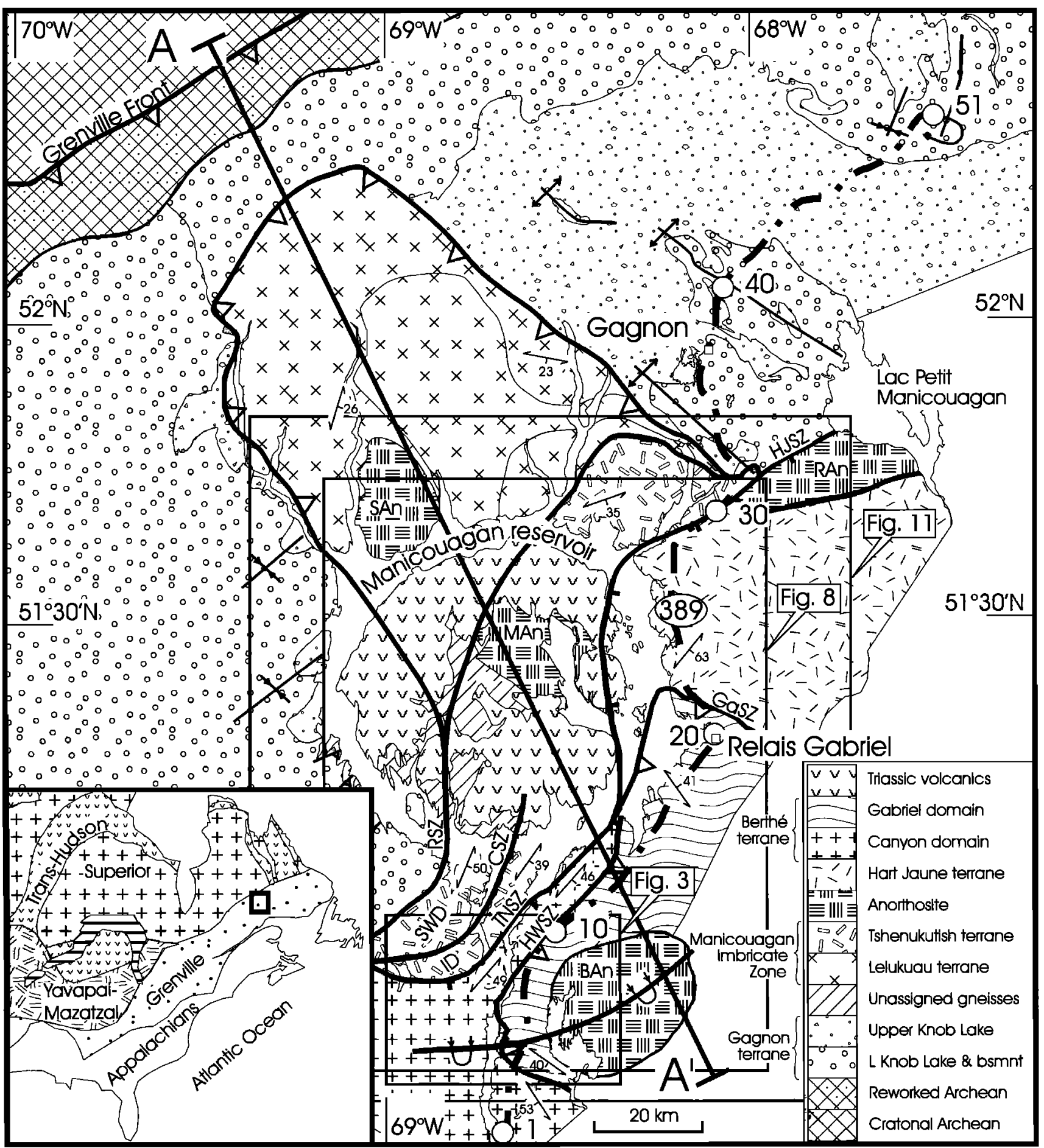

Figure 1. Geology adjacent to Line 55. Location is identified in index map in lower left. Dash-dot line is Highway 389 and Lithoprobe Line 55; white circles labeled 1, 10, etc. are shotpoints. BAn, Berthé anorthosite; MAn, Memory anorthosite; RAn, Raudot anorthosite; SAn, Seignelay anorthosite. Heavy solid lines are faults: CSZ, Cryptic shear zone; GaSZ, Gabriel shear zone; HJSZ, Hart Jaune shear zone; HWSZ, Highway shear zone; RSZ, Relay shear zone; TNSZ, Triple-Notch shear zone. ID, Island domain; SWD, Southwest domain. Geology after Kish [1968], Clarke [1977], Avramtchev [1983], Gobeil [1997a, b], as well as unpublished mapping by Hynes and by A. Indares and T. Rivers (Memorial University). Knob Lake Group is Paleoproterozoic, Lelukuau terrane is Labradorian $(\sim 1650 \mathrm{Ma})$, Tshenukutish and Hart Jaune terranes are Pinwarian ( $1450 \mathrm{Ma})$ and Berthé terrane is Grenvillian (1100-1000 Ma). Boxes mark the locations of Figures 3, 8, and 11. Section $A^{\prime}{ }^{\prime}$ is depicted on Figure 14. 
paper, 1998]. Hart Jaune terrane is also Pinwarian and may be correlative to the Manicouagan Imbricate Zone, but neither it nor Berthe terrane shows evidence of such deep burial; the maximum pressures estimated for metamorphism there are less than $900 \mathrm{MPa}$ [A. Hynes et al., Lithoprobe Line 55: structure, timing and implications for the Grenvillian orogeny in eastern Quebec, submitted to Canadian Journal of Earth Sciences, 1998; hereinafter referred to as submitted paper]. They were, however, metamorphosed at 1011-990 Ma [Scott and Hynes, 1994]. The Hart Jaune - Triple Notch shear system therefore delineates a fundamental break in the orogen, beneath which high-pressure rocks were rapidly extruded to the northwest, shortly after $1030 \mathrm{Ma}$, to produce the Manicouagan Imbricate Zone. It is the controls on this extrusion that are the main concern of this paper. The analysis that follows was intended primarily to determine the three-dimensional form of the high-pressure rock package, by delineating the subsurface form of the Hart Jaune--Triple Notch shear system and the Relay shear zone (RSZ, Figure 1) which respectively overlie and underlie the Manicouagan Imbricate Zone.

\section{Determining Subsurface Structure from Seismic Reflection Data}

The primary constraints on the subsurface disposition of the high-pressure metamorphic rocks are derived from Lithoprobe Line 55 (Plate 1), a seismic reflection line that was run along Highway 389 adjacent to the Manicouagan Reservoir [Eaton et al., 1995] (Figure 1). Although this seismic line passes southeast of the Manicouagan Imbricate Zone, most of the structures in the region dip to the southeast, so that the Manicouagan Imbricate Zone extends beneath the seismic line. The optimal seismic line with which to probe the deep structure would have been oriented NNW, perpendicular to the regional tectonic strike. Highway 389 is, however, the only road in the region covered by Figure 1 along which a seismic survey is possible. Line 55 follows a circuitous route that is rarely perpendicular to tectonic strike at the surface and is in some cases subparallel to it, leading to uncertainty in interpretation of the geometry of what is depicted by the seismic data. Although this uncertainty in the case of Line 55 is unusually severe, it is a typical feature of land-based seismic surveys. A common way in which to deal with the uncertainty is to conduct crossing surveys at intervals along seismic lines, so that three-dimensional seismic reconstruction can be performed. In this case, both the limited road network and funding constraints made this option impossible. We show here, however, that with some simple assumptions we may use the disposition of the line to provide a threedimensional representation of the subsurface structure in the vicinity of the line.

Lithoprobe Line 55 consists of 60 -fold vibroseis data, collected using 8-56 Hz sweeps, a $50 \mathrm{~m}$ group interval, and $18 \mathrm{~s}$ correlated records sampled at $4 \mathrm{~ms}$. A symmetrical split was employed, with a maximum offset of $6150 \mathrm{~m}$. Processing included refraction statics, dip moveout, and migration. Subsequent in-house processing applied noise attenuation and threshold filtering.
A major question that arises in the interpretation of seismic reflection data from crystalline terranes is the source of the observed reflectivity. In attempting to interpret Line 55, we adopted the working hypothesis that the bulk of the reflectivity was derived from gneissic foliation like that observed in outcrop. The predominant feature of the gneissic foliation is compositional layering, typically with alternations of biotite-rich and biotite-poor layers, or of amphibole/ pyroxene-rich and amphibole/pyroxene-poor layers, depending on the mineralogical characteristics of the rocks involved. Such layering may be inherited from primary compositional layering, may have developed through metamorphic differentiation during deformation, or may result from the transposition of rock masses of different composition into layered forms due to high strain. In all cases, however, the velocity contrasts and density contrasts between layers are probably high enough to be a factor in the development of seismic reflectivity [cf. Hurich and Smithson, 1987; Milkereit and Eaton, 1998], especially in circumstances in which compositional layering occurs on several scales, not just that of the outcrop. Although outcrop-scale folding dictates that such foliation will have variable attitudes, data collected in the well-exposed regions along the shores of the reservoir indicate that the attitudes of foliations are broadly consistent over large $(>10 \mathrm{~km})$ domains. This consistency permits prediction of the configuration of reflect-ions due to the attitudes of the foliations in the subsurface.

On the assumption that the maxima of foliation distributions are responsible for any reflections observed, calculating the attitudes expected of reflectors along specific portions of the seismic line based on observed surface structures is a straightforward procedure. The path followed by seismic energy, from source to reflector and back to receiver, lies in the plane containing the attitude of the seismic line and the normal to the reflector surface (Figure 2a). (Note that for clarity we show paths for sources offset from the shotpoints, i.e., before the corrections conducted during stacking.) Two adjacent shotpoints on a line (e.g., $S$ and $T$ on Figure 2a), and the two points on a reflector surface sampled from these shotpoints (e.g., $P$ and $Q$ ), all lie on this same plane and define the section observed on the seismic record, which we refer to as the seismic plane. In the special case for which the seismic line trends perpendicular to the strike of the reflector surface, the seismic plane is vertical. In this case, the seismic profile is equivalent to a vertical section, and the dip of the line joining the reflectors (line $P Q$ ) is an approximation (for migrated data) to the true dip of the reflector. In the general case, the seismic plane is inclined to the vertical, and the angle between the horizontal line in this inclined plane and the line joining the reflectors, which appears as an "apparent dip" on the seismic profile, is in fact the pitch of the reflector surface in the seismic plane. These retationships are depicted stereo-graphically in Figure $2 b$, in which a foliation plane is treated as the reflector surface, and the seismic plane is the plane containing its normal and the seismic line. The apparent dip of the reflector would be the angle $\delta$. The "depth" of a reflector beneath a given shotpoint, as observed in the seismic profile, is the two-way travel time required to traverse the minimum distance to the feature; in 

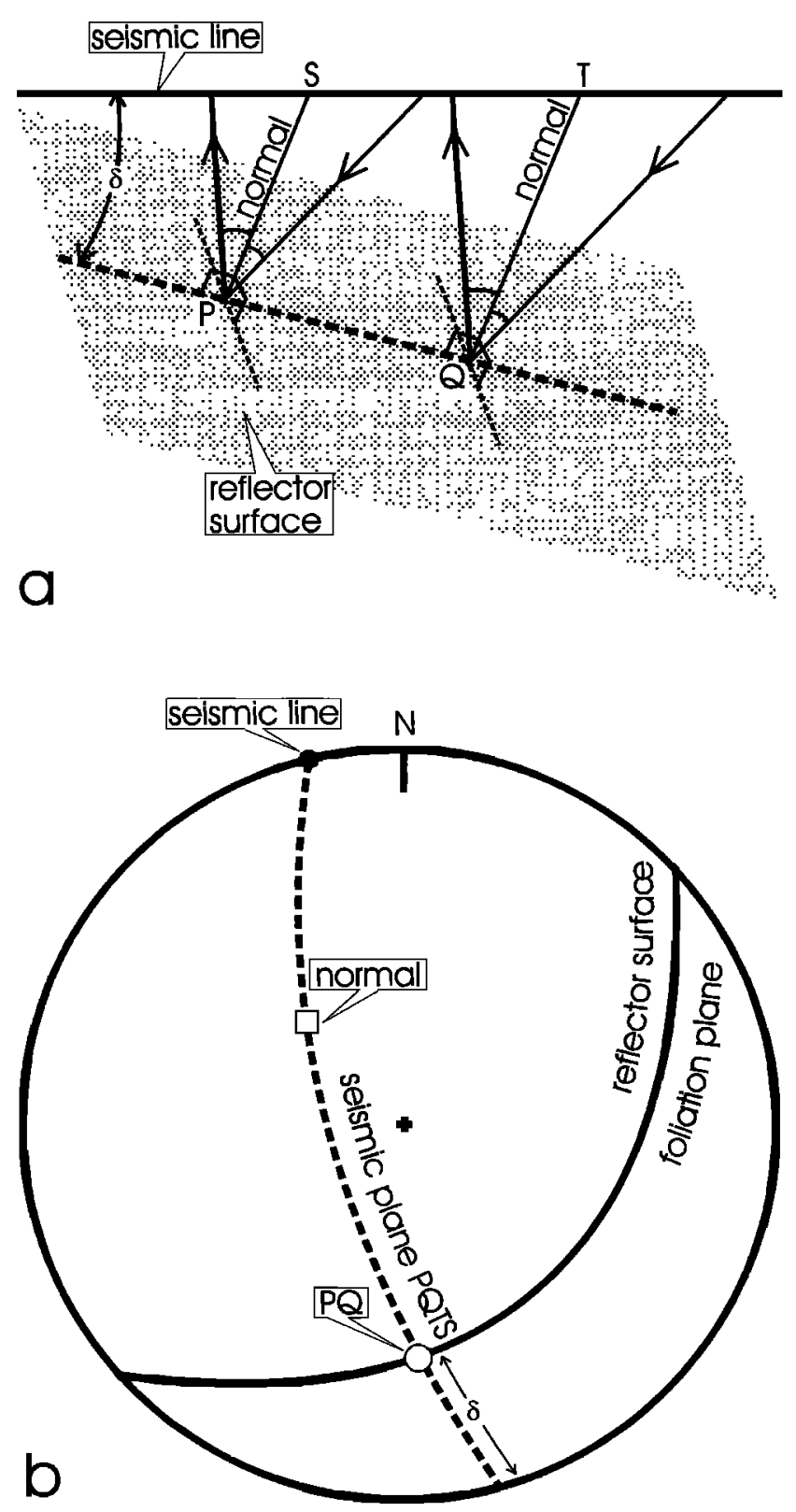

Fignre 2. (a) Perspective view of interaction of seismic survey with inclined reflector. Ray paths are shown for two shotpoints $S$ and $T$, with energy reflected from the reflector at $P$ and $Q$, respectively. (b) Stereographic projection illustrating the geometrical relationships of Figure $2 \mathrm{a}$. The "seismic plane" contains the seismic line and the pole to the reflector surface. The "dip" of the reflector that would be observed in the seismic profile is the angle $\delta$.

the general case this distance is not vertical (see, for example, SP and TQ in Figure 2a). The dip and depth of a feature observed in a seismic profile are therefore actually a pitch angle and an apparent depth, except for features that strike parallel to the seismic line.

If the attitude and position of a feature that is a potential reflector surface are known, the geometric relationships illustrated in Figure 2 permit the calculation of both the pitch angle and the apparent depth of the feature on the seismic profile, provided the seismic velocity of the intervening rocks is known. Throughout this paper, we assume seismic velocities of $6 \mathrm{~km} \mathrm{~s}^{-1}$. As an illustration of the effectiveness of these kinds of calculation, we have determined the positions and attitudes we would expect for reflections from the gneissic foliations in the Canyon domain and the Island domain near shotpoints 6,7 , and 8 on Line 55 . The geology
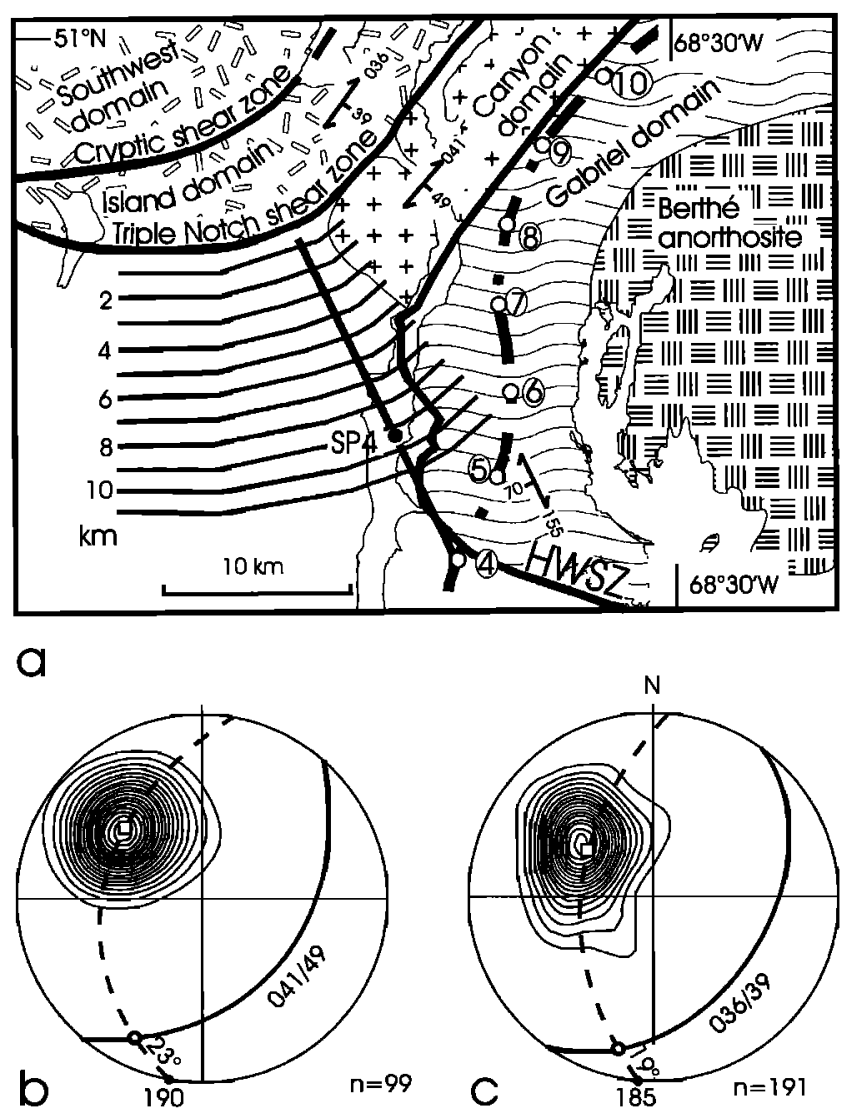

Figure 3. (a) Surface geology near SP 4. Legend as for Figure 1. Circled numbers are shotpoints. Solid circle labeled SP4 shows position in subsurface at which TNSZ is interpreted to be imaged (Figure 6). Evenly spaced solid black lines are structure contours on TNSZ in subsurface. Structural symbols indicate mean foliation attitudes in Canyon domain (cf. Figure 3b) and Island domain (cf. Figure 3c). (b) Lower hemisphere equal-area projection of foliation poles in Canyon domain near SP 6. Contouring using Spheristat [Pearce and Stesky, 1990]. Lowest level (outermost) contour is expected value for randomly distributed data; successively higher levels step up by $2 \sigma$, where $\sigma$ is statistical dispersion of data [Robin and Jowett, 1986]. Open square shows maximum eigenvector for distribution, solid great circle shows mean foliation, solid circle shows trend of seismic line at SP 6, dashed great circle shows seismic plane , and open circle shows expected pitch of reflector $\left(23^{\circ}\right.$ at 190$)$. (c) Lower-hemisphere equal-area projection of foliation poles in Island domain. Contouring and other symbols as for Figure 3b. 


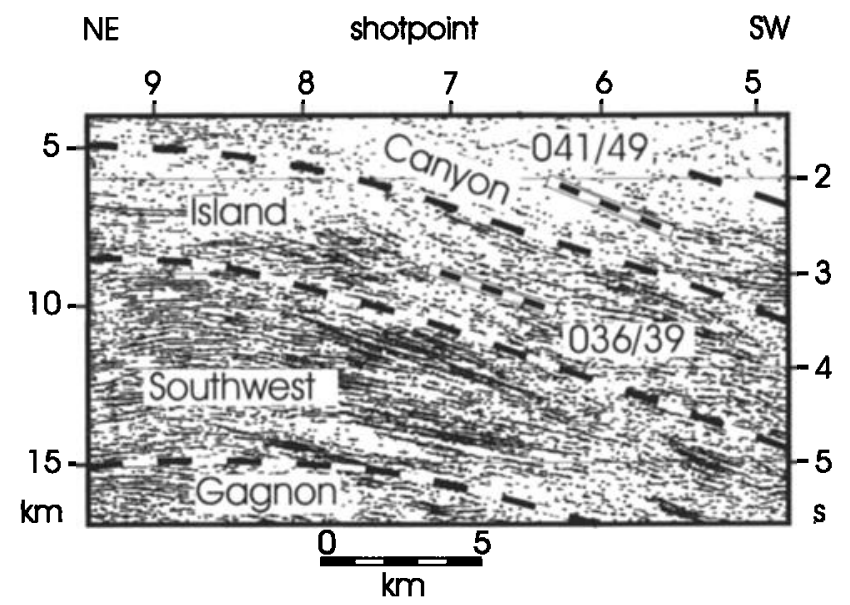

Figure 4. Part of Line 55, illustrating the consistency of gneissic foliation and seismic reflectors near shotpoint (SP) 6 and 7. Black/white bars are modeled attitudes of reflectors due to foliation in Canyon domain at SP 6 and Island domain at SP 7 based on the foliation attitudes of Figure 3. Dashed lines are interpreted positions of major faults. See Plate 1 for location in Line 55 profile.

around this part of the seismic line is illustrated in Figure $3 \mathrm{a}$. Gneissic foliations in the Canyon domain have very uniform attitudes of $041 / 49$ (Figure 3b; planar attitudes are specified in this paper using the "righthand rule"; the three-digit number is the strike, with a direction such that the dip bearing is $90^{\circ}$ clockwise from it; the two-digit dip angle is separated from the strike by a slash) and those in the Island domain have uniform attitudes of 036/39 (Figure 3c). Both the Canyon domain and the Island domain lie northwest of the seismic line (Figure 3a). The southeasterly dips of the foliations within these domains mean that the foliations are very favorably oriented to generate reflectors in the seismic survey. At shotpoint 6 (hereafter SP 6), where the seismic line trends at $190^{\circ}$, a stereographic analysis like that of Figure $2 \mathrm{~b}$ indicates that reflections from gneissic foliation in the Canyon domain should pitch $23^{\circ}$ at 190 (Figure 3b). Likewise, at SP 7 reflections from gneissic foliation in the Island domain should pitch $19^{\circ}$ at 185 (Figure 3c). The depths at which these reflectors should be observed may be derived from simple trigonometric calculations based on the surface relationships of Figure 3a. In the seismic profile, the attitudes of the reflectors at the expected depths are very similar to those calculated (Figure 4; the black-and-white bars are the modeled reflector attitudes). Note also in Figure 4 how the attitudes of reflectors observed in the Canyon and Island domains turn toward the horizontal at SP 8 and SP 9. This curvature is a direct result of the change in orientation of the seismic line, which brings it into parallelism with the strike of the foliation in the two domains (Figure 3a). In general on Line 55, the calculation of expected attitudes of reflectors from the attitudes of gneissic foliation at the surface produces remarkably good fits to the observations (see also Figure 5 and several of the other seismic profiles in the paper), providing strong support for the correctness of the hypothesis that the reflectors are parallel to the gneissic layering in the region.

In attempting to interpret the deep structure, however, it is more important to establish criteria by which the boundaries (shear zones, faults) between major tectonic units can be recognized. Where shear zones and faults are observed at the surface in the Manicouagan region and their attitudes can be reliably characterized from field data, they are typically parallel to the gneissic foliations in the domains they separate. On the seismic record for Line 55, domain boundaries are rarely associated with reflectors stronger than those we

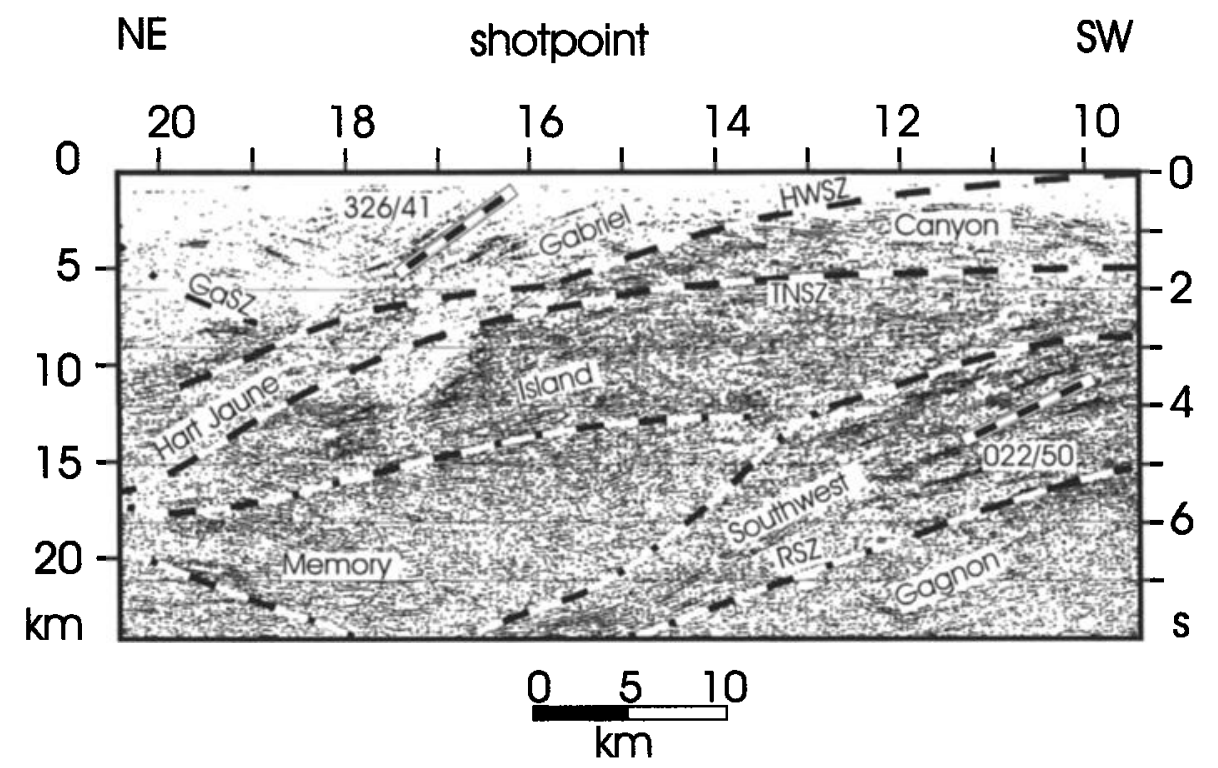

Figure 5. Part of Line 55 between SP 10 and 20. Black/white bars labeled 022/50 and $326 / 41$ are expected attitudes of reflectors from foliations in Southwest domain at SP 11 and Gabriel domain at SP 17, based on the attitudes of gneissic layering at the surface. 
identify with foliations internal to the domains, but their positions may in some cases be identified from the locations of boundaries between domains of contrasting reflectivity characteristics. For example, strong and laterally persistent reflectors characterize the Southwest domain at SP 10 and 12, but are absent in the overlying Island domain (Figure 5; note also that the reflectors have the attitudes expected from the attitudes of layering in the Southwest domain at the surface, as shown by the black-and-white bar marked 022/50). Almost without exception on the seismic record for Line 55, the boundaries between domains of contrasting reflectivity are parallel to the reflectors within domains on either side. In many cases we can very reasonably correlate these boundaries to shear zones and faults we observe at the surface (see below). We interpret these observations as indicating that the majority of shear zones imaged in the subsurface by the seismic survey are parallel to the local foliations.

We have estimated the true positions of reflectors by assuming, in general, constant dips between features observed at the surface and the same features at the depths at which their equivalent reflectors or reflectivity boundaries are observed on the seismic records. This has proved particularly useful for some of the fault boundaries, for which the strike is well known from the map pattern but the dip is less well constrained. Changes to the assumed dip modify both the apparent depth and the pitch angle. An increase in the dip of the reflector on Figure 2a, while retaining the same strike and outcrop position, would increase both the distance PS (the apparent depth of the feature at shotpoint $S$ ) and the pitch of the line QP in the plane PSTQ (the angle $\delta$ in Figure 2), which is the pitch that is actually observed in the seismic profile. This permits optimal adjustment of the dip to provide the best fit to the position and pitch of the observed reflectors. It also provides a test of whether the assumption of constant dip between the surface and the position of the feature where

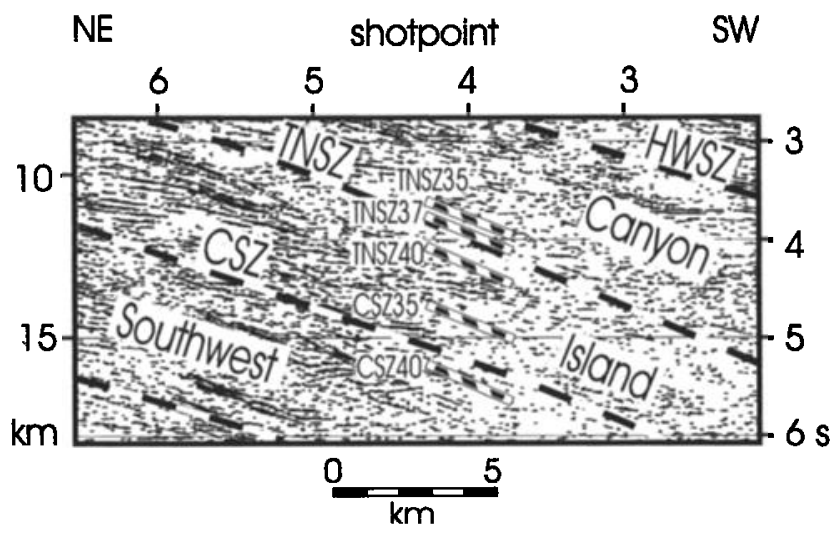

Figure 6. Calculated attitudes and positions for reflectors associated with Triple Notch shear zone (TNSZ) and Cryptic shear zone (CSZ) at SP 4, superposed on a portion of the profile for Line 55 . Barber's poles show positions and attitudes of reflectors from TNSZ, for strikes of 060 and dips of $35^{\circ}, 37^{\circ}$, and $40^{\circ}$, labeled TNSZ35, TNSZ37, and TNSZ40, and from CSZ, for strike of 060 and dips of $35^{\circ}$ and $40^{\circ}$ (CSZ35 and CSZ40). Heavy dashed lines show interpreted trajectories of TNSZ and CSZ. See Figure 3a for the local surface relationships. it gave rise to the reflector on the seismic record is correct, since both the pitch angle and the apparent depth of the observed reflector must be satisfied. In Figure 6, for example, we depict the calculated attitudes and positions for reflectors associated with the Triple Notch shear zone (the "barber's poles"), for a strike of 060 and dips of $35^{\circ}, 37^{\circ}$ and $40^{\circ}$ from the surface to the position sampled by seismic survey. The interpreted trajectory of the Triple Notch shear zone is consistent in depth and attitude with a $37^{\circ}$ dip in the subsurface. A similar analysis for the Cryptic shear zone brackets its dip between $35^{\circ}$ and $40^{\circ}$, also for a strike of 060 (Figure 5).

As a direct result of the assumptions inherent in our procedure, the modeling provides structure contours on the surfaces of faults and shear zones for the areas between their surface exposures and the positions at which they are sampled seismically (e.g., Figure 3a). The solid circle labeled SP4 on Figure $3 \mathrm{a}$ is directly above the position at depth at which we consider the Triple Notch shear zone was imaged at SP4 (the point on the Triple Notch shear zone that is closest to SP 4 in three dimensions). It lies northwest of the line because of the southeasterly dip of the Triple Notch shear zone. Its large horizontal distance from the seismic line graphically demonstrates the departure of the seismic plane from the vertical section when the regional strike is not perpendicular to the seismic line.

\section{Subsurface Structure Adjacent to Line 55}

We now report the results of applying the procedures outlined above to Lithoprobe Line 55 , proceeding downward from the top of the structural stack, at the southern end of the line, and concentrating particularly on the configuration of the shear zones bounding the high-pressure metamorphic rocks.

The Triple Notch shear zone is overlain by the Berthe nappe. The Berthe anorthosite in core of the nappe is above surface on Line 55, but rocks of the Canyon domain on the upper and lower flanks of the nappe are clearly imaged between SP 1 and 9 (Figure 7). At the southern end of Line 55 , the Triple Notch shear zone is more than $20 \mathrm{~km}$ horizontally from the line, but by SP 8 it comes within less than $10 \mathrm{~km}$ (Figure 8). A constant attitude of $035 / 45$ for the Triple Notch shear zone between the surface and its imaged position, which is similar to that of the foliations on either side of it (Figure 3a), would place it near $2 \mathrm{~s}$ two-way time (hereafter twt; see barber pole symbol on Figure 7). This corresponds to a real depth of $3.8 \mathrm{~km}$, displaced roughly $4 \mathrm{~km}$ to the NW of SP 8 (Figure 8). To the south, the depth of the Triple Notch shear zone increases markedly, although the apparent increase visible on the seismic section (Figure 7) is exaggerated by divergence of the surface trace of the shear zone from Highway 389. A general trajectory for the Triple Notch shear zone, parallel to reflectors in the seismic record, can be adequately modeled as far as SP 4 if it shallows as it swings to the west, from $45^{\circ}$ at SP 8 to $37^{\circ}$ at SP 4 (Figure 7).

Between SP 8 and SP 15 the surface trace of the Triple Notch shear zone is parallel to Highway 389 (Figure 8). Its trace on the seismic line is therefore essentially horizontal (Figure 5), and its position can be modeled with constant dips of $50^{\circ} \mathrm{SE}$ at depth. From SP 16 to SP 25, the position of the 


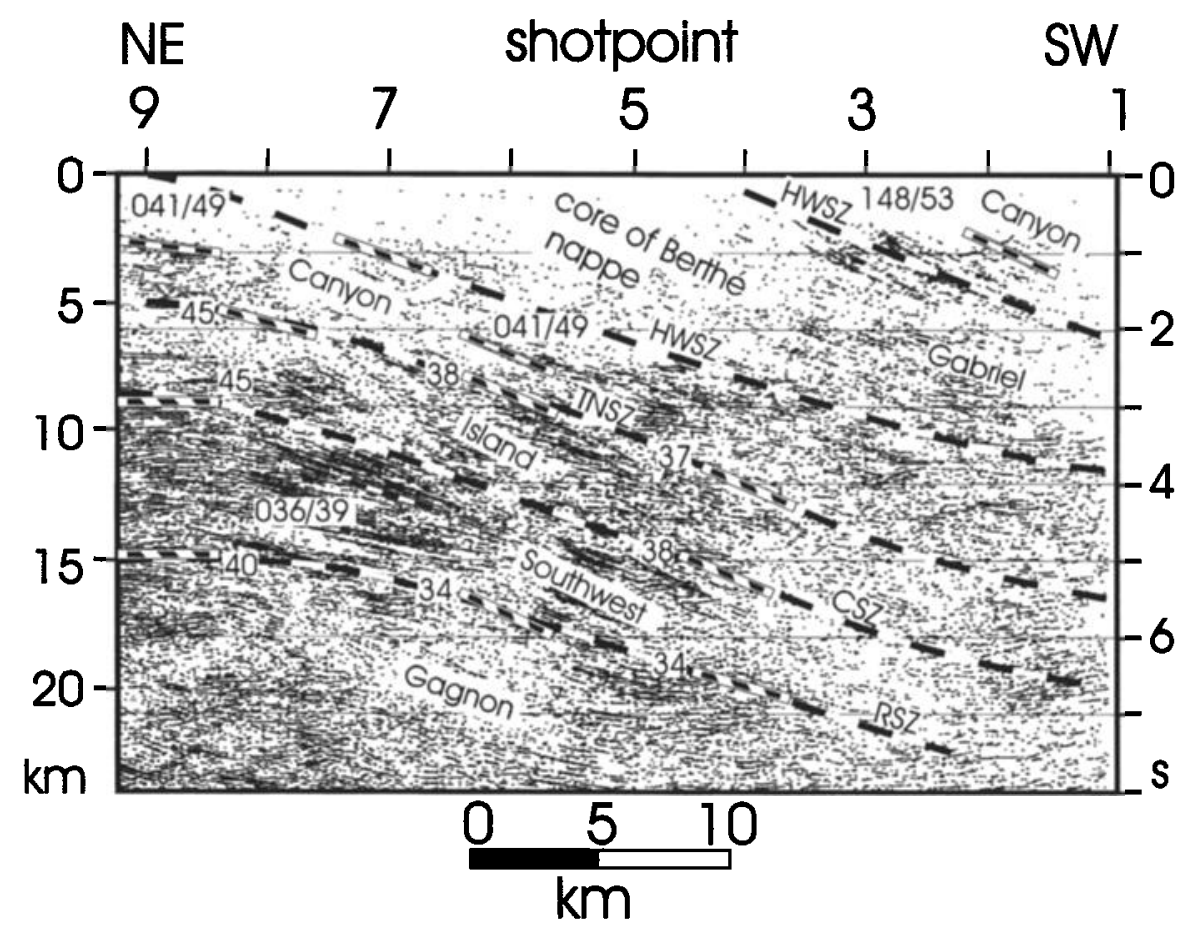

Figure 7. First $8 \mathrm{~s}$ of Line 55 record between SP 1 and 9. Heavy dashed lines show interpreted positions of major faults: Highway shear zone (HWSZ), Triple Notch shear zone (TNSZ), Cryptic shear zone (CSZ), and Relay shear zone (RSZ). Barber's poles show positions of faults calculated using constant dips from surface and strike at surface, labeled with dip used. Black/white bars show calculated positions and attitudes of reflectors inferred from regional foliation-attitudes at surface, labeled with strike and dip of foliation. Figure adjoins Figure 5 (see Plate 1 for overview).

surface trace is obscured by the reservoir and Triassic volcanic rocks, but the requirements that it pass east of the easternmost exposures of the Memory anorthosite on the central island and join the Hart Jaune shear zone in the NE of the reservoir place severe constraints on its position. The continuity of reflections associated with Hart Jaune terrane between SP 21 and 24 (Figure 9) requires that the Triple Notch shear zone arrivals at SP 21 are later than $5 \mathrm{~s}$ twt and, despite the increased distance between its surface trace and the seismic line produced by the curvature of Highway 389 (Figure 8), the Triple Notch shear zone can be modeled at such late arrivals only if its dip increases significantly north of SP 15. The attitude and position of the interpreted reflectors for the Triple Notch shear zone are well matched at SP 22 with dips of $70^{\circ}$ east (Figure 9), and the progressively later arrivals of reflections associated with the Island domain between SP 15 and SP 20 (Figure 5) are also consistent with $70^{\circ}$ dips. It appears therefore that the dip of the Triple Notch shear zone increases significantly where its trace swings from northeast to north in the segment of the line between SP 15 and SP 23 (Figure 8). Between SP 23 and SP 27, we cannot provide a reasonable interpretation of the trace of the Triple Notch shear zone on the seismic profile without relaxing the assumption of constant dip with depth. We can, however, fit the seismic data very well if the Triple Notch shear zone in this region is lystric, with dips decreasing from $60^{\circ}$ at the surface to $35^{\circ}$ at the depths imaged by the seismic waves (see Figure 8). The regional form of the Triple Notch shear zone in the subsurface that emerges from our analysis is that of a moderately southeast dipping surface, with a substantial northward kink immediately east of the Manicouagan Reservoir, on which the dips are considerably steeper (Figure 8).

Relay shear zone is the lower bounding surface for Tshenukutish terrane in the southwest and is contiguous with an unnamed shear zone in the northeast (Figure 1). On Line 55 between SP 4 and SP 12, the Relay shear zone can be confidently modeled with constant dips of $35^{\circ}$ to $40^{\circ}$ southeast, from the surface to the depths of seismic sampling. As was the case for the Triple Notch shear zone, there are few geological constraints on the exact position of the surface trace of the Relay shear zone crossing the central island. In this case, the problem is compounded by the substantial excursion taken by the road between SP 15 and 25, which causes the seismic signature of the fault to be displaced to late arrival times, for which the signal is weak. In estimating the subsurface structure of the Relay shear zone where it crosses the reservoir, we have adopted a conservative interpretation, limiting the extent to which the fault is arcuate to the northwest as much as possible, and retaining constant dips of $40^{\circ}$ southeast to depth. This places the trace of the Relay shear zone beneath the northward extension of a zone of prominent reflectors developed between SP 7 and 12 (Figures 5 and 7), that are clearly associated with granitoids of the Southwest domain of Tshenukutish terrane exposed in the southwest of the reservoir. At and northeast of SP 14, the 


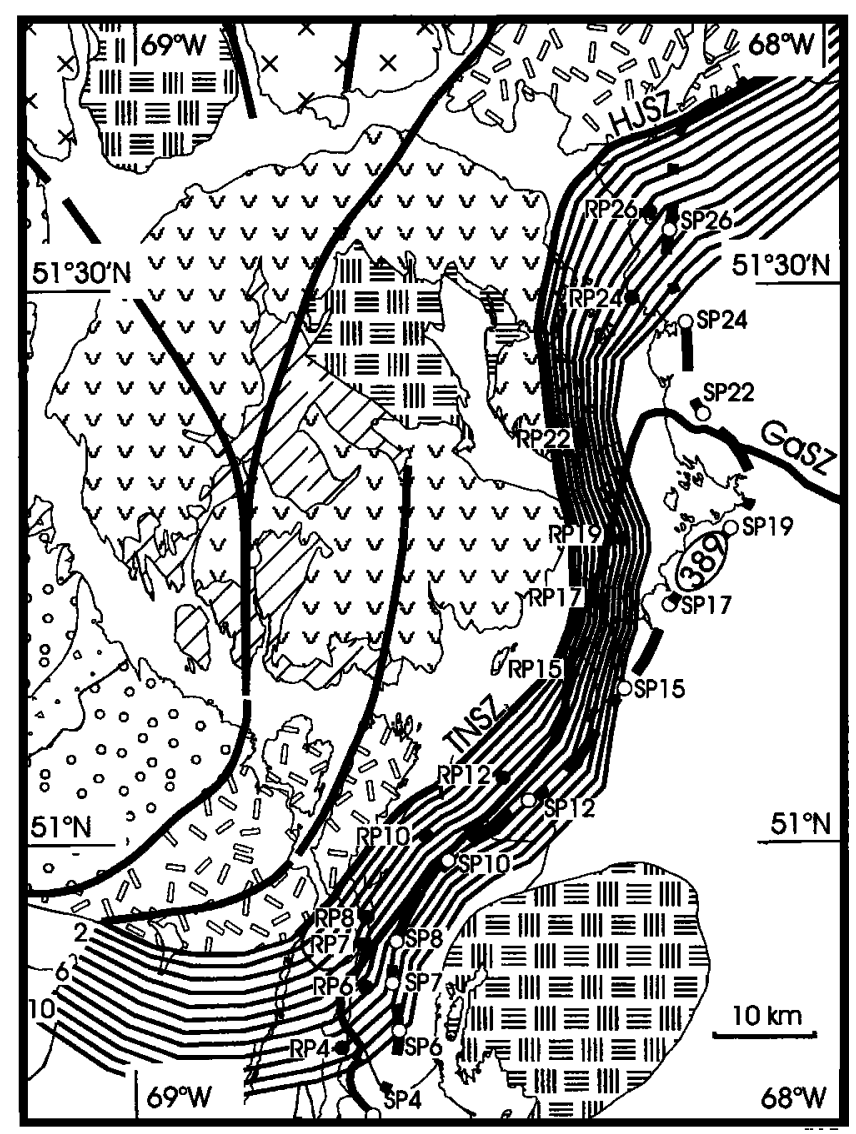

Figure 8. Structure-contour map for Triple Notch shear zone. Solid black lines show contours at $1 \mathrm{~km}$ intervals. Solid circles labeled RP 12, etc., show positions in subsurface from which reflectors are interpreted to be observed from shotpoints SP 12, etc. Open circles labeled 'SP12', etc., show surface positions of shotpoints. Legend for bedrock geology is as for Figure 1 .

distinctive, variably reflective unit associated with the Southwest domain is separated from the reflective, but more uniform unit of the Island domain by a reflection-poor unit (Figure 5). This unit is consistent with the projected location of the Memory anorthosite exposed on the central island (Figure 1). The upper, highly reflective unit (Island domain) is continuous to SP 20. The lower unit (Southwest domain) is sporadically evident as far north as SP 17 (Plate 1) and is consistently underlain by the Relay shear zone if its subsurface dip is $40^{\circ}$ (see interpreted trace of the Relay shear zone on Plate 1).

Note that on the seismic profile the pitch of the Relay shear zone changes from southwesterly between SP 1 and SP 7 (Figure 7) to northeasterly beyond SP 9 (Figure 5), tracing out a large apparent antiform. This antiform, which is present in all earlier arrivals as well, is due largely to the northwestward curvature of the road centered on SP 9 (Figure 3a), although northward curvature of the trace of the fault is a contributing factor. The curve in the road moves the shotpoints closer to the generally southeast-dipping surfaces, thereby causing reflections from them to arrive earlier, and changes the pitches of the reflectors either side of the position of closest approach. A much more prominent synform evident in the seismic record near SP 21 (e.g., Figure 10) has a similar origin, being due to eastward curvature of the road centered at Relais Gabriel (Figures land 8). Both apparent structures are artifacts that demonstrate the dangers inherent in the simplistic interpretation of seismic profiles as vertical sections.

Between SP 20 and SP 27, the position of the base of Tshenukutish-domain rocks is less certain because the seismic signal beneath the Triple Notch shear zone is not well developed. Reflectors similar in character to those we correlate to Tshenukutish terrane at SP 17 are, however, present in the record at SP 22 near 7 s twt, and at SP 27 near 4 s twt, with pitches compatible with $35^{\circ}$ southeast dips for the features responsible for them. Extrapolation of the structure contours northward for the Relay shear zone from SP 20, with dips shallowing to $35^{\circ}$ as the strike swings from northerly to northeasterly (Figure 11) provides a good fit to these observations and requires a substantial thickness for Tshenukutish terrane beneath SP 27, as indicated by the surface geology immediately north of the reservoir (Figure 1). Between SP 27 and SP 31, prediction of reflectors is complicated by the large fold in the base of Tshenukutish terrane defined by the surface geology (Figure 1). There is no signal in the seismic record that can be traced convincingly from the surface appearance of the SSE striking limb of this fold between SP 31 and SP 32 (Figure 9), probably because of interference from the other limb. Our structure-contour map (Figure 11) was constructed in this region by adopting a broadly parallel style for the large-scale fold, with dips of $25^{\circ}$ for the southeast striking limb, consistent with the observed attitudes of the foliation in the basal Tshenukutish rocks at the surface.

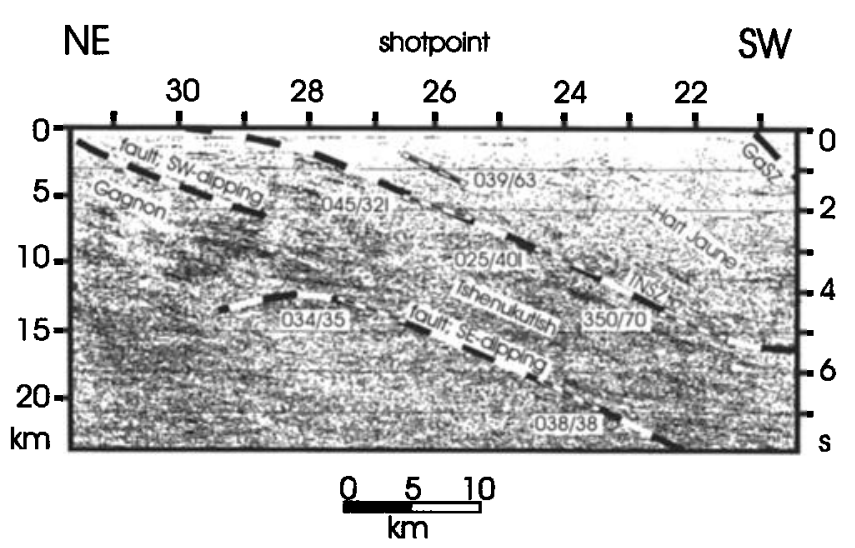

Figure 9. First $8 \mathrm{~s}$ of Line 55 record between SP 21 and 31. Heavy dashed lines show interpreted positions of Triple Notch shear zone (TNSZ), a short segment of the Gabriel shear zone (GaSZ, top right-hand corner), and fault at base of Tshenukutish terrane. Note that the fault at the base of Tshenukutish terrane is interpreted to have images from both a SE and SW dipping segment. Symbols are as for Figure 7. Labels $025 / 401$ and $045 / 321$ are attitudes for TNSZ at depth, in regions in which it was modeled as lystric. Figure adjoins Figure 5. 


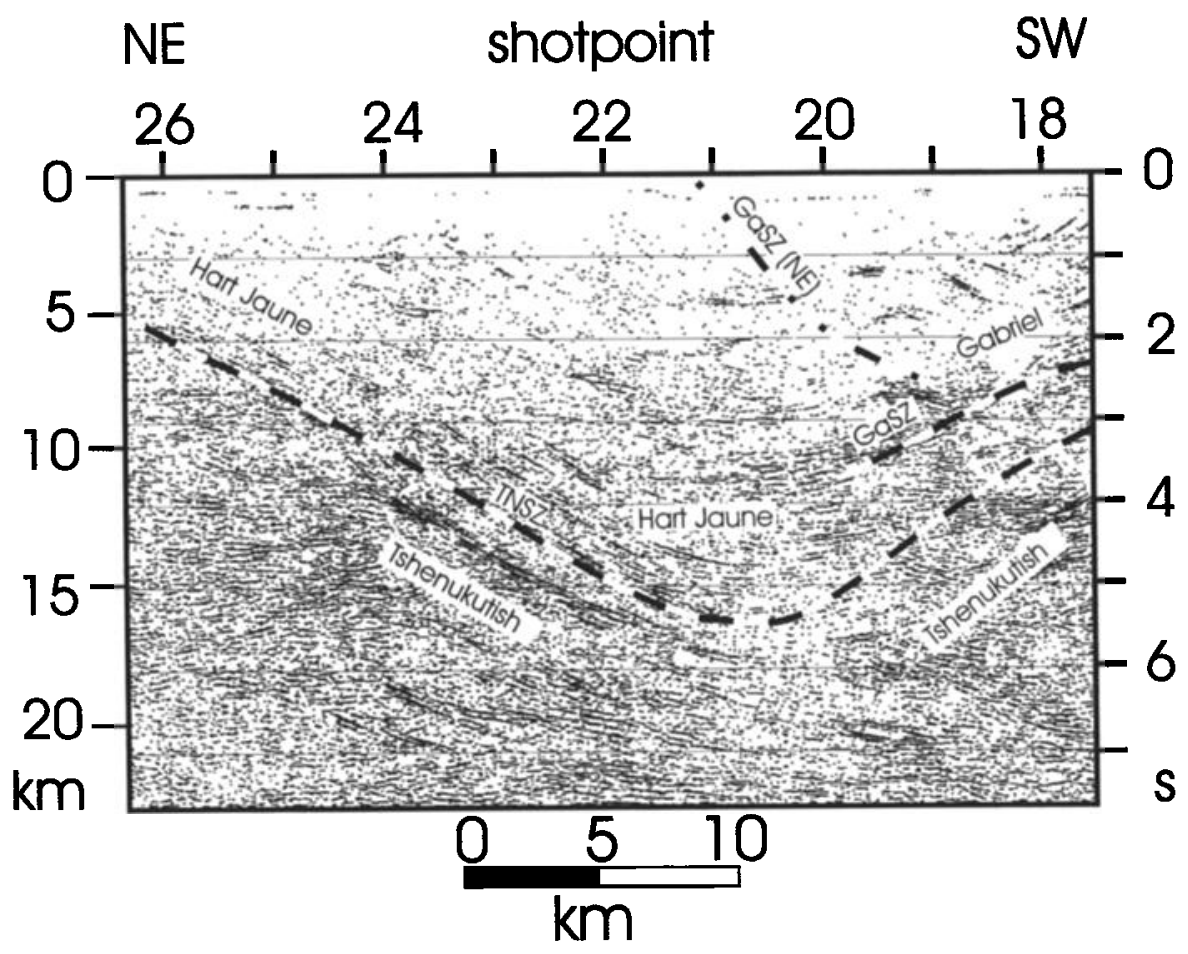

Figure 10. Part of Line 55 between SP 18 and 26, illustrating continuity of reflectors associated with Hart Jaune terrane in northeast, where they underlie SW dipping limb of the Gabriel shear zone (GaSZ NE) and farther SW, where they underlie SE dipping limb of Gabriel shear zone (GaSZ).

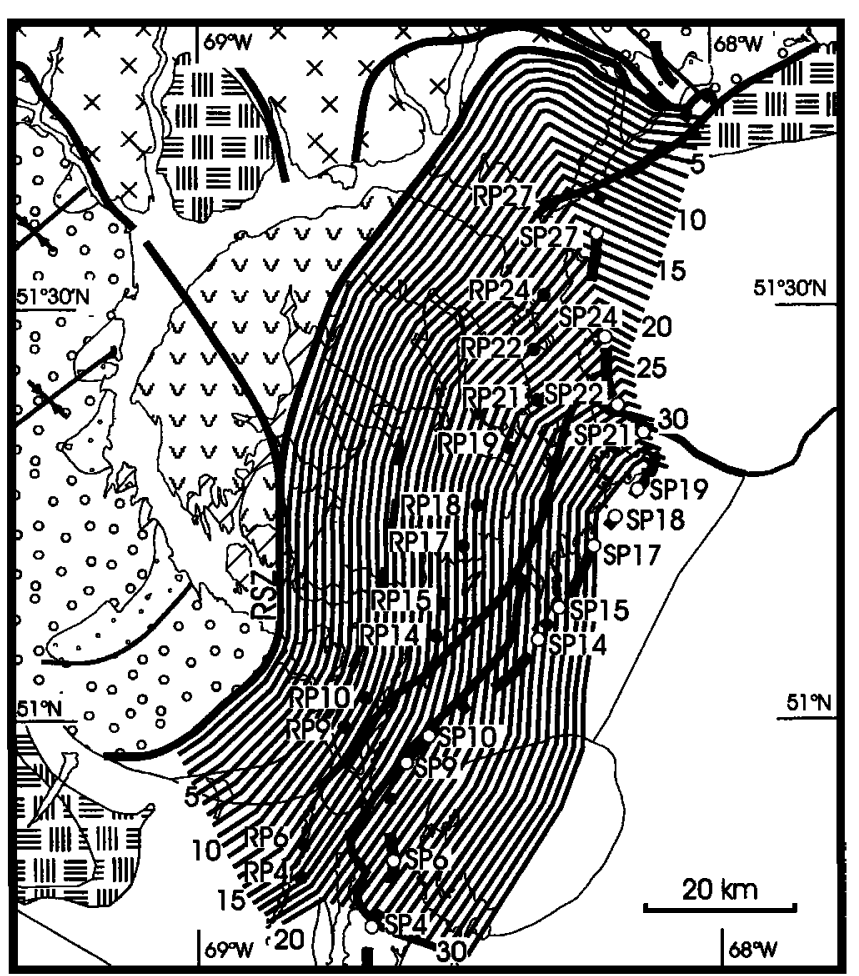

Figure 11. Structure-contour map for Relay shear zone. Solid black lines are contours at $1 \mathrm{~km}$ intervals. Solid circles labeled RP 10, etc., are positions in subsurface from which reflectors are interpreted to be observed from shotpoints SP 10 , etc. Legend for bedrock geology is as for Figure 1.
Surface geology indicates that rocks of Lelukuau terrane are pinched out between those of Tshenukutish terrane and Gagnon terrane northwest of SP 31 and, despite the very broad exposure of such rocks to the northwest of the reservoir, they are again pinched out to the southwest before the Relay shear zone intersects the shoreline in the southwest of the reservoir (Figure 1). The lobe of Lelukuau terrane is therefore limited to a region adjacent to Tshenukutish terrane. Dips within this region are generally shallow (A. Indares et al., submitted paper, 1998). The seismic interpretation provides no evidence for any substantial thickness of Lelukuau-terrane rocks extending to depth beneath rocks of Tshenukutish terrane. Reflectors beneath the interpreted position of the Relay shear zone are generally sporadic and discontinuous, so that no robust extrapolations to exposed units are possible. The interpretation we adopt here is that the Relay shear zone is underlain by rocks of Gagnon terrane all along Line 55, in which case the broad lobe of Lelukuau terrane is a thin lip-like feature in front of and only partly beneath Tshenukutish terrane [see also Eaton et al., 1995].

North of SP 32, Line 55 lies entirely within rocks of Gagnon terrane, where it crosses the axes of the major, northwest-trending cross-folds at high angle (Figure 1). The mapped regional antiforms and synforms, defined by the stratigraphy of the Knob Lake Group, are clearly visible on Line 55 and are evident in arrivals as late as $3 \mathrm{~s}$ twt (Figure 12). Attitudes of gneissic layering in Gagnon terrane match the observed pitches of reflectors very well, implying that in this part of Line 55 reflectors were in the vertical plane. There is no distinctive signal at the contact between the lower and 


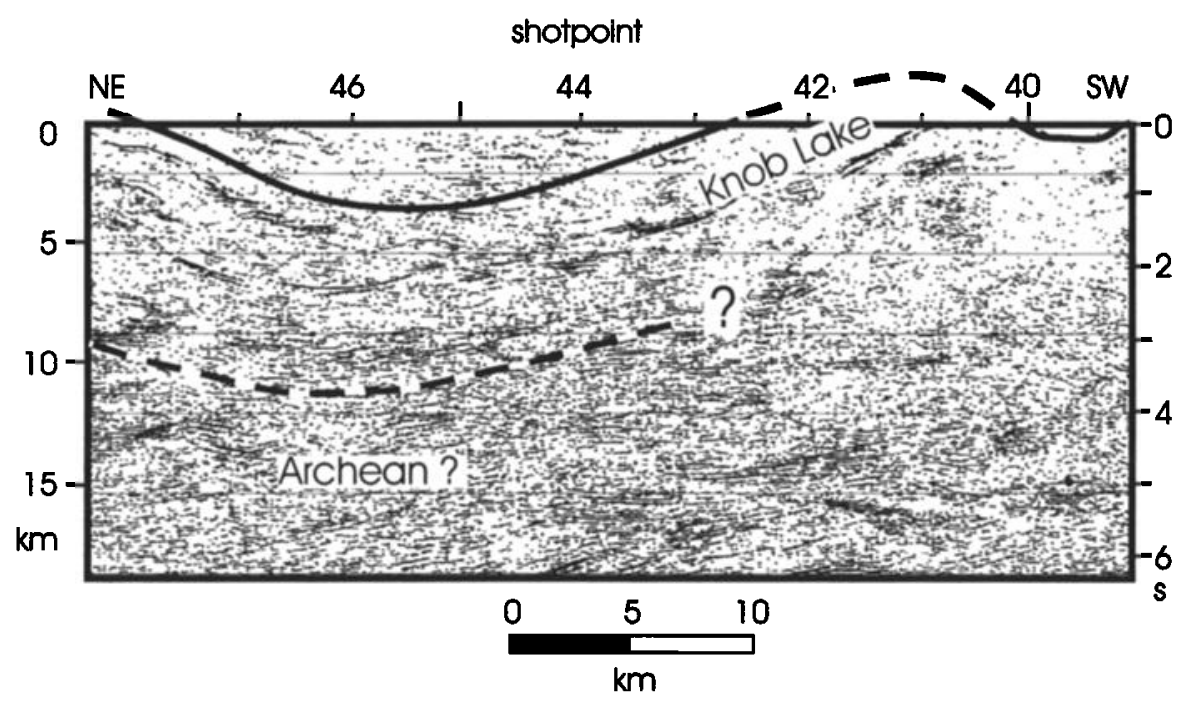

Figure 12. Part of Line 55 between SP 39 and 48. Thick dashed line shows interpreted Archean/Proterozoic décollement. Solid line shows interpreted position of Upper Knob Lake/Lower Knob Lake boundary. Where it crosses $0 \mathrm{~s}$ twt, its position is constrained by surface geology; elsewhere it has been drawn parallel to the prominent reflector approximately $1 \mathrm{~s}$ twt beneath it.

upper parts of the Knob Lake Group, where iron formation and marble are known to occur. There is a strong reflector within the lower part of the Knob Lake Group (Figure 12) that may be due to iron formation [Eaton et al., 1995]. If this is iron formation, it is structurally considerably below that exposed at the surface and appears to be separated from it by a (basement?) imbricate or imbricates. Alternatively, the reflector may be due to a thick mafic sill. Archean basement cannot be clearly distinguished from Knob Lake metasediments on the seismic record. This is not surprising, since field observations indicate that the metasediments are interleaved with basement rocks in many places (A. Indares and T, Rivers, personal communication, 1997), and the metamorphic grades in the metasediments are high, so that reflection coefficients with granitoid basement contacts may not be significant. Towards the northeastern end of Line 55, an approximate position for a décollement at the base of the thrust stack may be drawn beneath the zone of coherent reflectors on the migrated section, but the disposition of this surface farther southeast is unclear (Figure 12). At SP 30, the region we expect to be occupied by the imbricated units of Gagnon terrane exhibits very strong south-pitching reflectors (Figure 9) that we interpret to have originated from Tshenukutish terrane in the nose of the SSE plunging fold

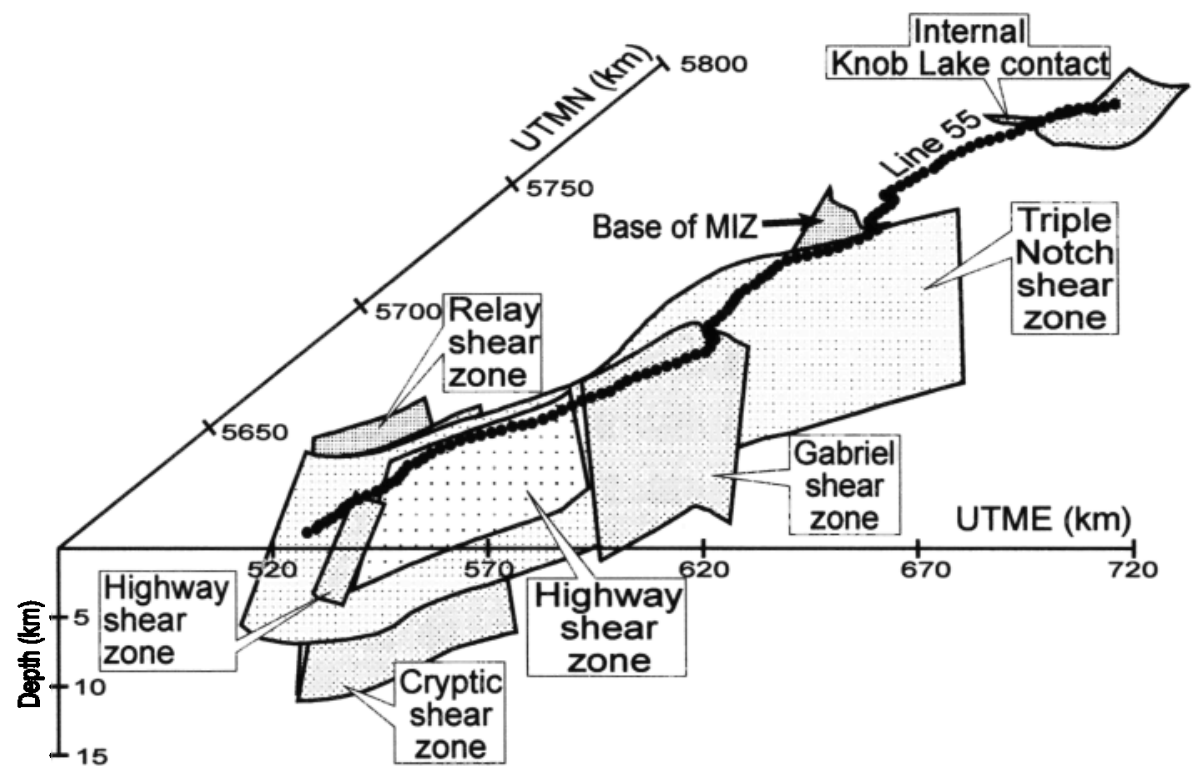

Figure 13. Perspective view of surfaces used in seismic modeling, looking northwest. The eight surfaces shown were derived from structure-contour maps for the surfaces. They were gridded to produce a total of 375,550 nodes in a corridor approximately $250 \mathrm{~km}$ long and $50 \mathrm{~km}$ wide. 
defined by the structure-contour map of the Relay shear zone (Figure 11). Farther south, the absence of a well-defined reflector or reflectivity boundary along the southern half of the line precludes a reliable estimate of the subsurface trajectory of the putative décollement at the base of the thrust stack. As a result, we have not identified the base of Gagnon terrane south of SP 32 (Plate 1).

\section{Seismic Modeling of Structure in the Upper Crust Along Line 55}

An independent check of the viability of our estimates of the subsurface structure of the upper crust in the neighborhood of Line 55 is provided by forward modeling of the characteristics of the seismic record we might expect to see from such subsurface structure. To this end, we used a simplified version of the subsurface structure we infer to generate a synthetic seismogram. The subsurface configuration we used consisted of a stratum-conformable surface within the Knob Lake Group at a depth corresponding to the position of the prominent reflector there, two surfaces corresponding to the Highway shear zone in the upper and lower limbs of the Berthé nappe, the Gabriel shear zone, the Triple Notch shear zone, the unnamed fault beneath Tshenukutish terrane, the Cryptic shear zone and the Relay shear zone (Figure 13). Each of these surfaces was represented by a set of closely spaced nodes at which the density changed by $10 \%$, thereby giving rise to weak elastic perturbations, and they were treated as if they lay in a medium of otherwise uniform characteristics, with a $P$ wave velocity of $6 \mathrm{~km} / \mathrm{s}$ and an $S$ wave velocity of $3 \mathrm{~km} / \mathrm{s}$. The program BMOD3D [Eaton, 1997], which uses the distorted-wave Born approximation, was then used to generate a synthetic seismogram for Line 55 . The elastic perturbations at each node are calculated from the difference between the sharp change that is modeled and a more smoothly varying background model, and are integrated across the entire volume, as described in more detail by Eaton [1997]. The first $8 \mathrm{~s}$ of the resulting seismogram (Plate 2) correlate remarkably well to those for the seismogram of Line 55 (Plate 1). They illustrate clearly the viability of the subsurface geometry we have constructed and, given the simplicity of the assumptions involved in our procedures, lend a great deal of confidence to our geometric inferences.

\section{Implications for Deep Structure and Upward Transport of Deeply Buried Rocks}

The structure-contour maps we have derived from the line permit the construction of vertical sections. A section trending NNW, from the Berthe anorthosite through the broadest embayment of the Manicouagan Imbricate Zone, illustrates many of the important features of the eastern Quebec Grenville that are apparent from analysis of the seismic data (Figure 14). On this section, structure in the triangular zone beneath the surface position of Highway 389 is constrained by the structure-contour maps. Outside this zone, the characteristics of the section are derived from extrapolation parallel to the regional tectonic strike. The depth to the Moho within the triangular zone on the section was identified from the marked decline in reflectivity on Line 55, which can be traced continuously from $13.5 \mathrm{~s}$ twt at SP 1 to more than $16 \mathrm{~s}$ twt at SP 50 [Eaton et al., 1995] (Plate 1). Farther northwest it was derived from inversion of the gravity field [Zheng and Arkani-Hamed, 1998; A. Hynes et al, submitted paper, 1998].

A major feature of the section is the prominent ramp beneath Tshenukutish terrane [see also Eaton et al., 1995] up which the Manicouagan Imbricate Zone must have been transported. The combination of this ramp and the southward shallowing of the Moho suggests that the Archean basement terminates in the subsurface somewhere near the southeastern end of the section. In regions of crustal thickening like the Grenvillian orogen, the efficacy of crustal ramps in promoting the rapid exhumation of deeply buried rocks has been recognized for some time [e.g., Jamieson and Beaumont, 1988]. In essence, the ramp constrains the slope at the base of an orogenic wedge to be steep, which in turn imposes a steep slope on the top of the orogenic wedge [cf. Davis et al., 1983], thereby promoting elevation and the consequent removal of the overlying rocks. In the case of the Manicouagan Imbricate Zone, deep burial followed by rapid

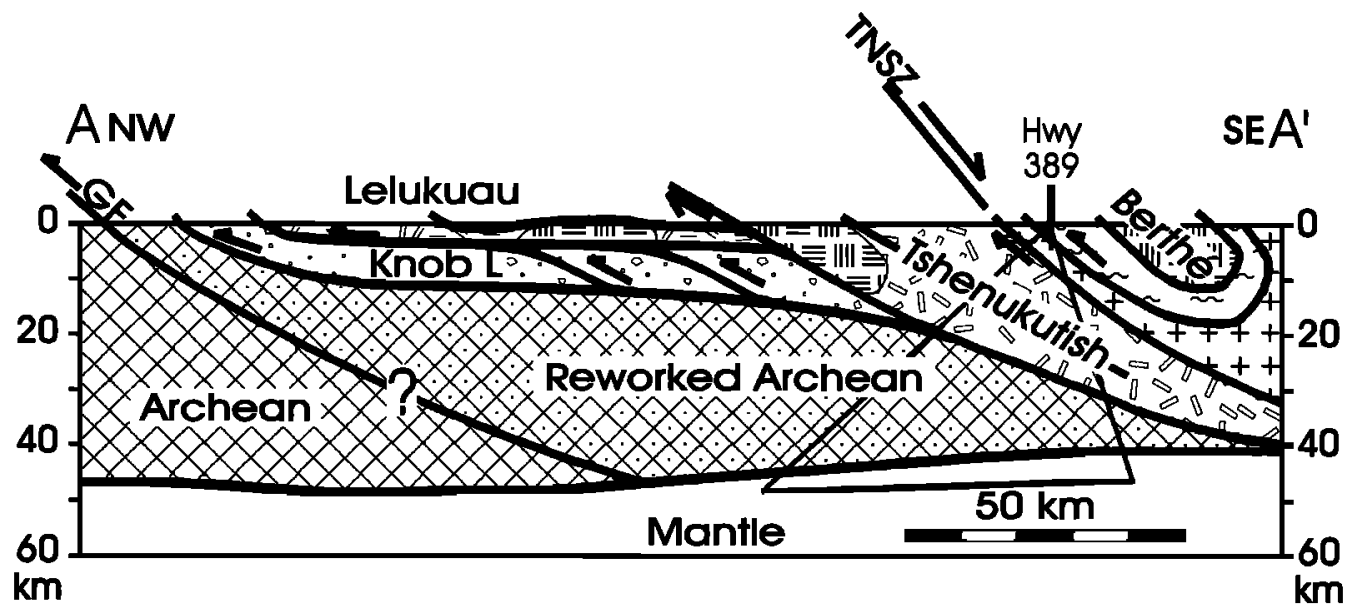

Figure 14. Vertical section along line $\mathrm{AA}^{\prime}$ (Figure 1). 


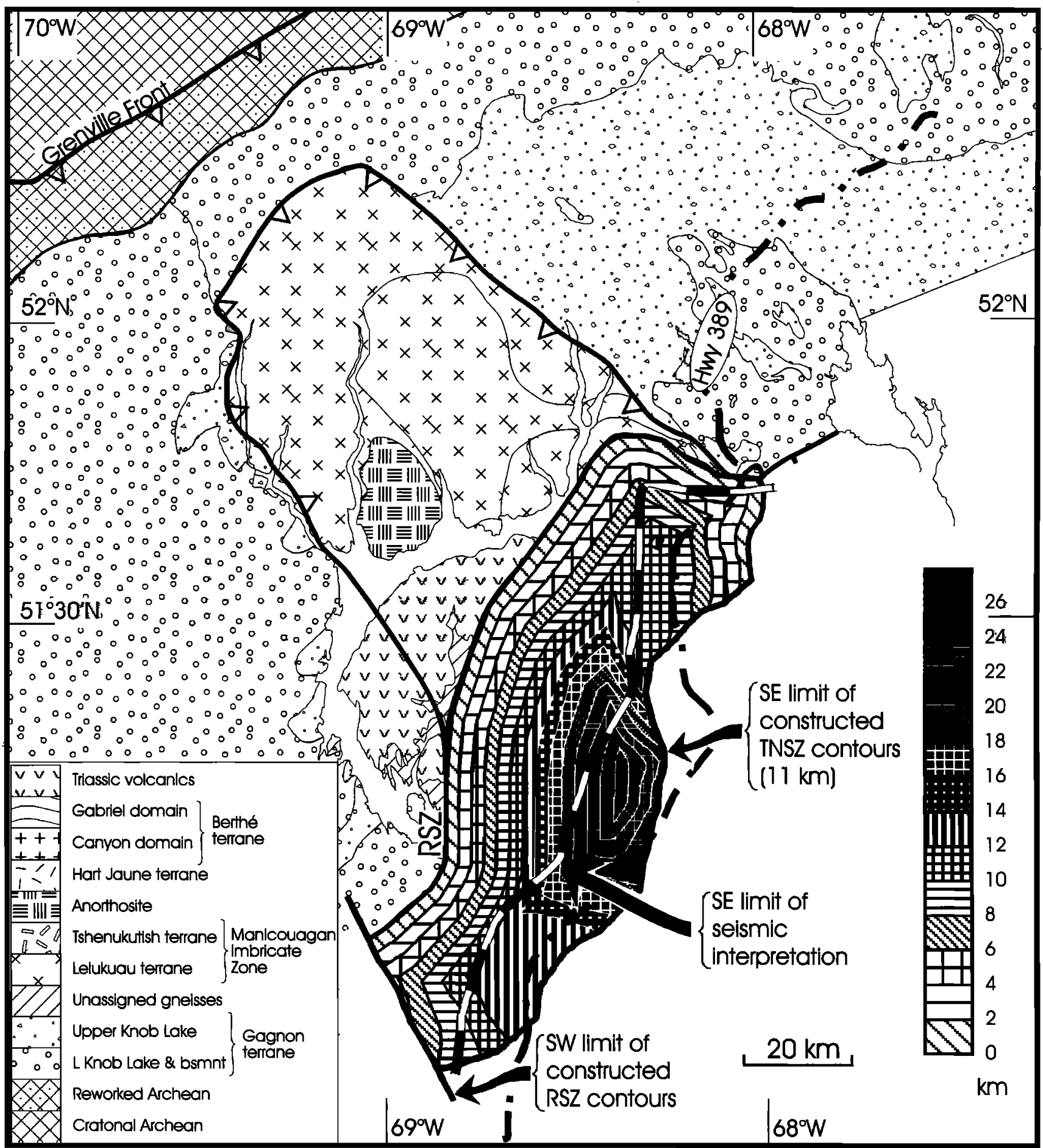

Figure 15. Isopach map for Tshenukutish terrane, derived from structure-contour maps for TNSZ and RSZ. Preserved thickness is differentially shaded, as in reference column at right. Heavy dashed line is SE limit of structure contours whose position is constrained by observed reflectors. To SE of this line, structure contours on RSZ were constructed by linear extrapolation; isopachs are therefore less well constrained than to NW.

unroofing requires transfer of the rocks from the footwall of the orogenic wedge into the orogenic wedge itself during the accretionary process, in a process of basal accretion like that modeled by Chemenda et al. [1995]. The Manicouagan Imbricate Zone is, however, a very local feature in the context of the Grenvillian orogen as a whole, and the information we have obtained about the subsurface structure in its vicinity provides a compelling argument for why rocks were so effectively unroofed there rather than throughout the orogen.

The total preserved thickness of rocks of Tshenukutish 


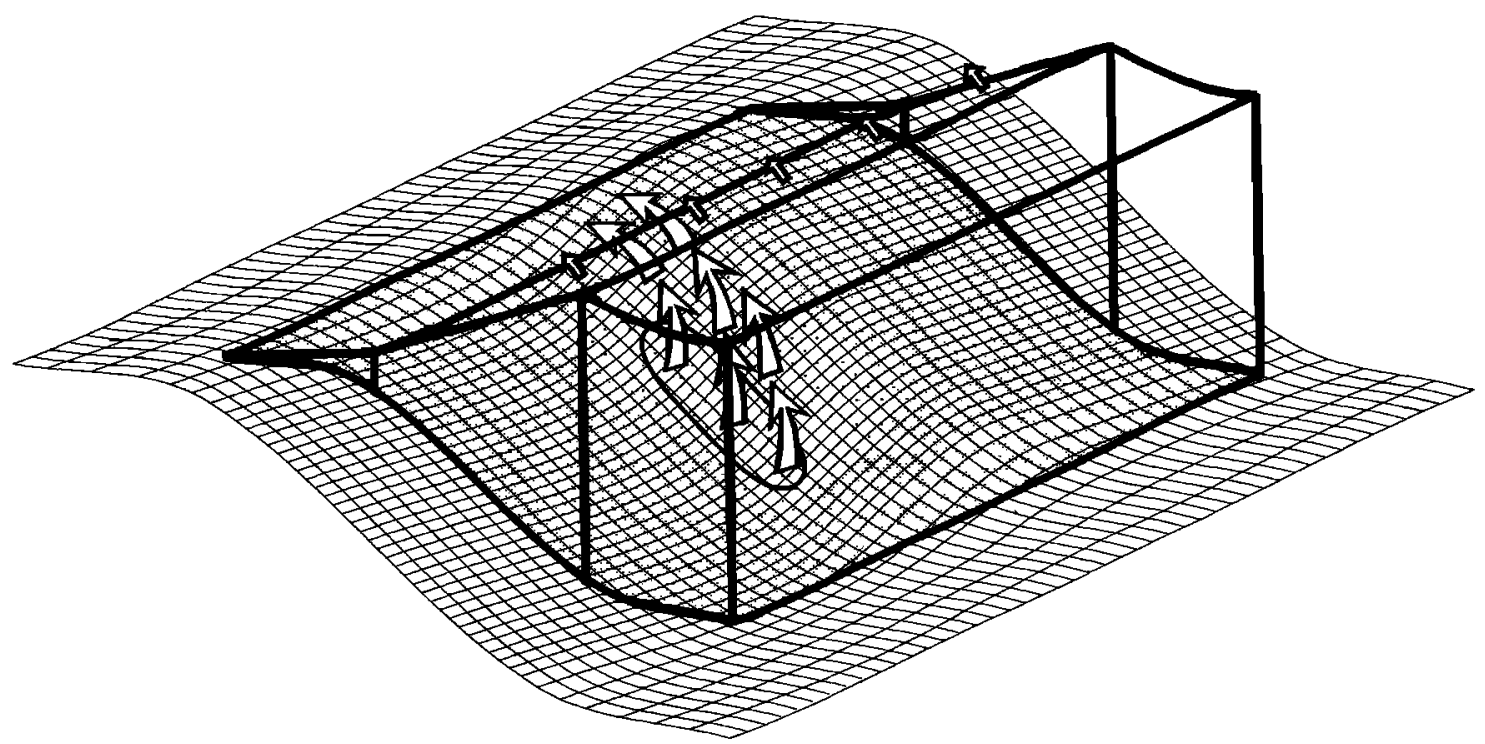

Figure 16. Schematic illustration of influence of lateral ramp on flow within overlying orogenic wedge. The lateral ramp is only lightly shaded and is oriented anticlockwise with respect to the main ramp. The thick solid lines outline the form of the orogenic wedge overlying the ramp.

terrane in the subsurface between its surface exposure and Highway 389 may be assessed from the differences in depth of the Triple Notch shear zone and the Relay shear zone (Figure 15). In the subsurface the Tshenukutish-domain rocks occur in a NNE trending lozenge-shaped block, with vertical thicknesses of more than $24 \mathrm{~km}$ west of SP 17. The form of the easternmost part of the lozenge (east of the dashed line on Figure 15) is not well constrained because it is derived from extrapolation of the structure contours for the Relay shear zone beyond the depths at which it is imaged on Line 55. The lozenge-like shape of the block is, however, suggested even by the isopachs for the region northwest of the positions of the Relay shear zone imaged on Line 55, where no extrapolation was necessary to construct the isopachs. It requires dramatic tapering of the underlying Archean crust toward the east in the vicinity of the Manicouagan Reservoir. In the context of regional ENE trends for the Grenvillian orogen, and tectonic transport toward the northwest for the Grenvillian orogeny in eastem Quebec and western Labrador [Rivers et al., 1993; Connelly et al., 1995], this eastward tapering is indicative of a markedly lateral ramp. Indeed, the lateral character of the ramp is clear from the general $\mathbf{S}$ form of the structure contours for the Relay shear zone (Figure 11).

The broad embayment of the Manicouagan Imbricate Zone northwest of the Manicouagan Reservoir is directly adjacent to the thick subsurface lens of Tshenukutish rocks and the lateral ramp (Figure 15), and it is in this embayment that the originally most deeply buried rocks are preserved (A. Indares et al., submitted paper, 1998). The lateral ramp appears to have provided circumstances that were particularly effective for the extrusion of deep-seated continental rocks. A simple physical analogy to this situation is that of a viscous fluid squeezed between two rigid plates; outward flow of the fluid between the two plates will be much enhanced in any channel defined by a concavity in the surface of one of the plates. The lateral ramp in the basement may have provided just such a concavity. In Figure 16 we illustrate our conception of the controls on flow within the orogenic wedge by the geometry of the ramp. The regional basement ramp (shaded and hatched) imposes a geometry on the orogenic wedge (outlined in thick black lines). This geometry promotes the flow of material upward through the part of the orogenic wedge that overlies the ramp, as illustrated by the short black arrows. A lateral lamp within the regional ramp (the lighter shaded part of the ramp) distorts the pattern of flow within the orogenic wedge, as illustrated by the longer grey arrows, promoting the flow of material into the concavity produced by the ramp and enhancing the flow upward through the concavity. It also provides an attractive mechanism for basal accretion, since stress concentrations on the convexity in the footwall surface (marked by the ellipse) may promote the dislodging of material from the footwall there and its transfer into the orogenic wedge.

\section{Conclusions}

Our interpretation of the seismic reflection data in the Manicouagan region has provided a clear picture of the subsurface structure around the Manicouagan Imbricate Zone. In part this is because Lithoprobe Line 55 has provided unusually good correlations between the attitudes of gneissic foliations at the surface and the attitudes of seismic reflectors, leaving little doubt that many of the reflectors in the upper half of the crust are parallel to gneissic foliations. These correlations have permitted us to demonstrate that many of the reflections observed come from outside the vertical plane. The reflection record is therefore far removed from a vertical section and is, in fact, not a section at all. Many of the large 


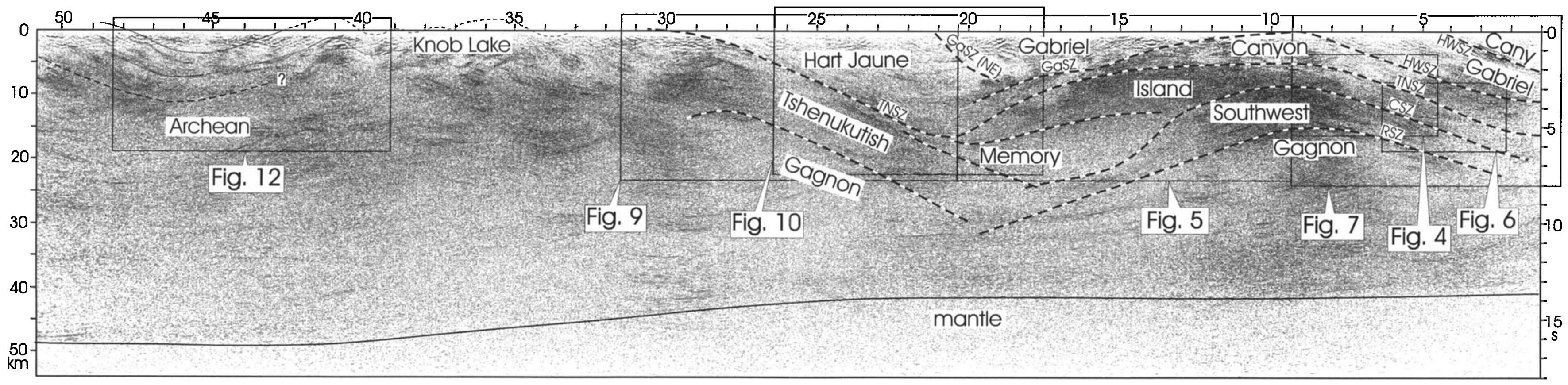

Plate 1. Seismic profile for Line 55 (Figure 1), with interpreted positions of tectonic boundaries. Boxes indicate locations of later figures. Note that the magnified figures used different processing parameters that enhance reflectivity contrasts in the first $8 \mathrm{~s}$ twt. 


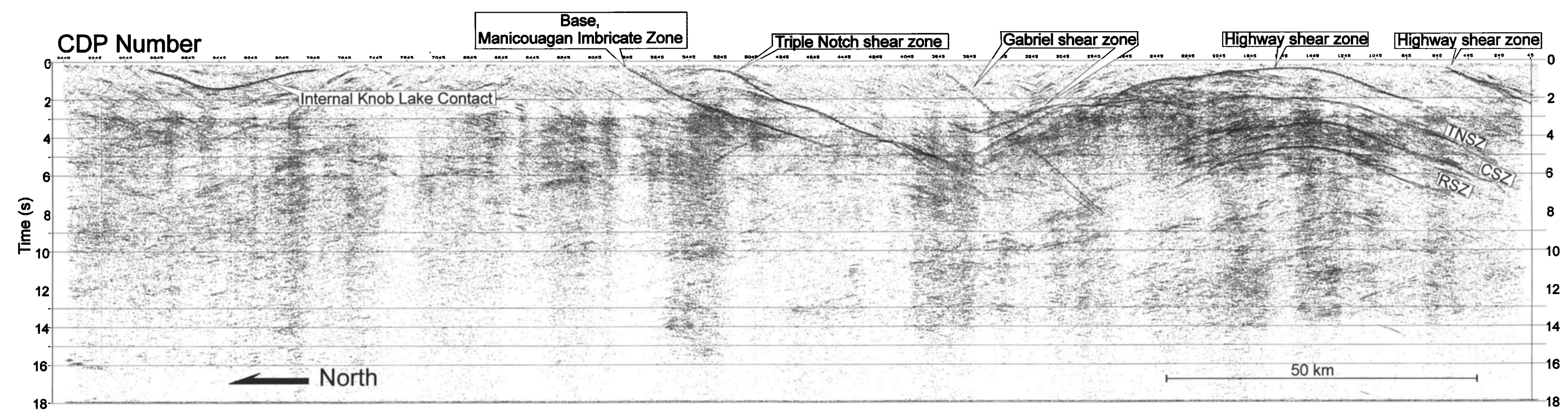

Plate 2. Synthetic seismogram for Line 55 derived from geometry depicted on Figure 13, using BMOD3D, a three-dimensional seismic modeling program using the Born approximation [Eaton, 1997 . The
seismogram has been adjusted to provide essentially no vertical exaggeration, with scales the same as those 
structures apparent on the record are, furthermore, artifacts of the disposition of the line. Only in the northern part of the line, where its trend runs perpendicular to regional strikes for considerable distances, does the seismic record bear a simple relationship to a structural section. Such problems are to be expected in regions of structural complexity and where road access is not optimal. By incorporating information from conventional structural studies, we have been able to circumvent some of these problems and have even used them to advantage. A conclusion that may be drawn from our work is, however, that the seismic profiles collected along crooked lines in structurally complex terranes may be very misleading without some independent assessment of the regional attitudes of subsurface reflectors.

The analysis of Line 55 has permitted the identification of a large-scale lateral ramp in the subsurface. The extrusion of the high-pressure rocks of the Manicouagan Imbricate Zone, which immediately overlie the ramp, and are distributed in a broad embayment adjacent to it, may have been a direct result of the existence of the ramp. Denudation rates are probably higher in the regions overlying ramps because of the effect of basal slope on the geometry of accretionary wedges, but it is the lateral character of the ramp in the Manicouagan region that was probably most important in effecting the extrusion, by providing a channel through which material could flow rapidly to shallow depths. The close association of the highpressure rocks with the subsurface ramp suggests that similar aspects of the surface geology may permit the recognition of lateral structures at depth elsewhere in the Grenville and in other orogens. The association, however, requires further testing, and it should be possible in other regions in which there is adequate subsurface control. Such subsurface control is derived largely from seismic data. Although seismic surveys of orogens have not generally been conducted with the aim of identifying and characterizing transverse structures, we have demonstrated that this is not necessarily an insurmountable problem.

Acknowledgments. This study was financed largely by grants from the Natural Sciences and Engineering Research Council (Canada) through their Operating Grants Program and the Lithoprobe program. Some of the structural data used were collected by Alger St-Jean and Steve St-Cyr. The seismic data were acquired under contract to Enertec Geophysical. Processing was by CGG Geophysics, Canada. The authors have appreciated stimulating discussions with André Gobeil, Aphrodite Indares, and Toby Rivers and constructive comments from journal reviewers. Lithoprobe contribution 972.

\section{References}

Andersen, T. B., and B. Jamtveit, Uplift of deep crust during orogenic extensional collapse: $A$ model based on field studies in the SognSunnfjord region of westem Norway, Tectonics, 9, 1097-1111, 1990.

Andersen, T. B., B. Jamtveit, J. F. Dewey, and E. Swensson, Subduction and eduction of continental crust: Major mechanisms during continent-continent collision and orogenic extensional collapse, a model based on the south Norwegian Caledonides, Terra Nowa, 3, 303-310, 1991.

Avramtchev, L., Carte des gîtes mineraux du Québec, région de la Baie James, 16 maps., Déposition Publique, Que Minist. Energ. Ressour., 940, 1983.

Chemenda, A. I., M. Mattauer, J. Malavieille, and A. N. Bokum, A mechanism of syn-collisional rock exhumation and associated normal faulting: Results from physical modelling Earth Planet. Sci. Lett., 132, 225-232, 1995.

Chopin, C., Very-high-pressure metamorphism in the western Alps: Implications for subduction of continental crust, $R$. Soc. London Philos. Trans., Ser A, 321, 183-197, 1987.

Christensen, N. I., and W. D. Mooney, Seismic velocity structure and composition of the continental crust: A global view, J. Geophys. Res., 100, 9761-9788, 1995.

Clarke, P. J., Région de Gagnon, Rapp. Geol, Que. Minist. Richesses Na.t., 178, 1-79, 1977.

Connelly, J. N., T. Rivers, and D. T. James, Thermotectonic evolution of the Grenville Province of westem Labrador, Tectonics, 14, 202-217, 1995.

Davidson, A., A review of the Grenville orogen in its North American type area, $J$. Aust. Geol. Geophys., I6, 3-24, 1995.

Davis, D., J. Suppe, and F. A. Dahlen, Mechanics of fold-and-thrust belts and accretionary wedges, $J$. Geophys. Res., 88, 1153-1172, 1983.

Davy, P., and P. Gillet, The stacking of thrust slices in collisional zones and its thermal consequences, Tectonics, 5, 913-929, 1986.
Dewey, J. F., P. D. Ryan, and T. B. Andersen, Orogenic uplift and collapse, crustal thickness, fabrics and metamorphic phase changes: The role of eclogites, in Magmatic Processes and Plate Tectonics, edited by $\mathrm{H}$. M. Prichard, T. Alabaster, N. B. W. Harris and C. R. Neary, Geol. Soc. Spec. Publ., 76, 325-343, 1993.

Easton, R. M., The Grenville Province and the Proterozoic history of central and southern Ontario, in The Geology of Ontario, edited by P. C. Thurston, H.R. Williams, R. H. Sutcliffe and G. M. Stott, Spec. Vol. Pt. 2, 715-904, Ont. Min. N. Dev. and Mines, Sudbury, Ontario, 1992.

Eaton, D., BMOD3D: A program for three-dimensional modelling using the Bom approximation, Geol. Surv. Can. Open File, 3357, 1-25, 1997.

Eaton, D. W., A. Hynes, A. Indares, and T. Rivers, Seismic images of eclogites, crustal-scale extension, and Moho relief in the eastern Grenville province, Quebec, Geology, 23, 855858, 1995.

England, P., and G. Houseman, Finite strain calculations of continental deformation, 2, Comparison with the India-Asia collision zone, J. Geophys. Res., 91, 3664-3676, 1986.

England, P., and G. Houseman, Extension during continental convergence, with application to the Tibetan Plateau, J. Geophys. Res., 94, 17,561-17,579, 1989.

Gobeil, A., Géologie de la région du lac Lacoursière (22N08), Rapp. Geol., Que. Minist. Richesses Nat., 96-03, 0-14, 1997a.

Gobeil, A., Géologie de la région du lac Granmesnil (220/05), Rapp. Geol., Que. Minist. Richesses Nat., 96-04,0-12, $1997 \mathrm{~b}$.

Gower, C. F., U. Scharer, and L. M. Heaman, The Labradorian orogeny in the Grenville Province, eastern Labrador, Canada, Can. J. Earth Sci., 29, 1944-1957, 1992.

Hacker, B. R., L. Ratschbacher, L. Webb, and D. Shuwen, What brought them up? Exhumation of the Dabie Shan ultrahigh-pressure rocks,
Geology, 23, 743-746, 1995.

Hsa, K. J., Exhumation of high-pressure metamorphic rocks, Geology, 19, 107-110, 1991.

Hurich, C. A., Kinematic evolution of the lower plate during intracontinental subduction: an example from the Scandinavian Caledonides, Tectonics, 15, 1248-1263, 1996.

Hurich, C. A., and S. B. Smithson, Compositional variation and the origin of deep crustal reflections, Earth Planet. Sci. Lett., 85, 416. 426, 1987.

Hynes, A, and A. R. St-Jean, Metamorphic signatures of faulting in the ManicouaganReservoir region, Grenville province, eastern Quebec, Can. Mineral., 35, 1173-1189, 1997.

Hynes, A., J. Arkani-Hamed, and R. Greiling, Subduction of continental margins and the uplift of high-pressure metamorphic rocks, Earth Planet. Sci. Lett., 140, 13-25, 1996.

Indares, A., Eclogitized gabbros from the eastern Grenville Province: textures, metamorphic context, and implications, Can. J. Earth Sci., 30, 159-173, 1993.

Indares, A, Gamet-kyanite clinopyroxenites and garnet-kyanite restites from the Manicoluagan Imbricate Zone: A case of high-P-high-T metamorphism in the Grenville province, Can. Mineral., 35, 1161-1171, 1997.

Indares, A, G. Dunning, R Cox, D. Gale, and J. Connelly, High-pressure, high-temperature rocks from the base of thick continental crust: Geology and age constraints from the Manicouagan Imbricate Zone, eastern Grenville province, Tectonics, I7, 426-440, 1998.

Jamieson, $\mathbf{R} A$., and $C$. Beaumont, Orogeny and metamorphism: a model for deformation and pressure-temperature-time paths with applications to the central and southern Appalachians, Tectonics, 7, 417-445, 1988.

Kish, L., Hart Jaune River area, Rep., 132, pp. 1 98, Quebec Dep. of Nat. Res. and Geol., Quebec, 1968.

Milkereit, B., and D. Eaton, Imaging and 
interpreting the shallow crystalline crust, Tectonophysics, 286, 5-18, 1998.

Pearce, G. W., and R. M. Stesky, Spheristat: Orientation analysis and plotting for $M S-D O S$ computers, Frontenac Wordsmiths, Brockville, Ontario, 1990.

Platt, J. P., Dynamics of orogenic wedges and the uplift of high-pressure metamorphic rocks Geol. Soc. Am. Bull., 97, 1037-1053, 1986.

Rivers, T., Revised stratigraphic nomenclature for Aphebian and other rock units, southern Labrador Trough, Grenville province, Can. J. Earth Sci., 17, 668-670, 1980.

Rivers, T., The northern margin of the Grenville province in westem Labrador - Anatomy of an ancient orogenic front, Precambrian Res., 22, $41-73,1983$.

Rivers, T., Lithotectonic elements of the Grenville province: Review and tectonic implications, Precambrian Res., 86, 117-154, 1997.

Rivers, T., and F. C. Mengel, Contrasting assemblages and petrogenetic evolution of corona and noncorona gabbros in the Grenville Province of western Labrador, Can. J. Earth Sci., 25, 1629-1648, 1988.

Rivers, T., J. Martignole, C. F. Gower, and A. Davidson, New tectonic divisions of the Grenville Province, southeast Canadian Shield, Tectonics, 8, 63-84, 1989.

Rivers, T., J. A. M. van Gool, and J. Connelly, Contrasting tectonic styles in the northern Grenville province: Implications for the dynamics of orogenic fronts, Geology, 21, 1127-1130, 1993.

Robin, P. -Y. F., and C. Jowett, Computerized density contouring and statistical evaluation of orientation data using counting circles and continuous weighting functions, Tectonophysics, 121, 207-223, 1986.

Scott, D. J., and A. Hynes, U-Pb geochronology along the Manicouagan Corridor, preliminary results: evidence for ca. $1.47 \mathrm{Ga}$ metgmorphism, Lithoprobe Rep., 41, 109-111, University of British Columbia, Vancouver, 1994.
Wang, X. M., J. G. Liou, and S. Maruyama, Coesite-bearing eclogite from the Dabie Mountains, central China: Petrogenesis, P-T paths and implications for regional tectonics, $J$. Geol., 100, 231-252, 1992.

Zheng, Y., and J. A. H. Arkani-Hamed, Joint inversion of gravity and magnetic anomalies of eastern Canada, Can. J. Earth Sci., 35, 832853, 1998.

D. Eaton, Depertment of Earth Sciences, University of Western Ontario, London, Ontario, Canada N6A 5B7.

A. Hynes, Department of Earth and Planetary Sciences, MoGill University, 3450 University Stroet, Montreal, Quebec, Canada H3A 2A7 (andrew@ eps.mcgillca)

(Received June 9, 1998;

revised November 20, 1998;

accepted November 23, 1998.) 